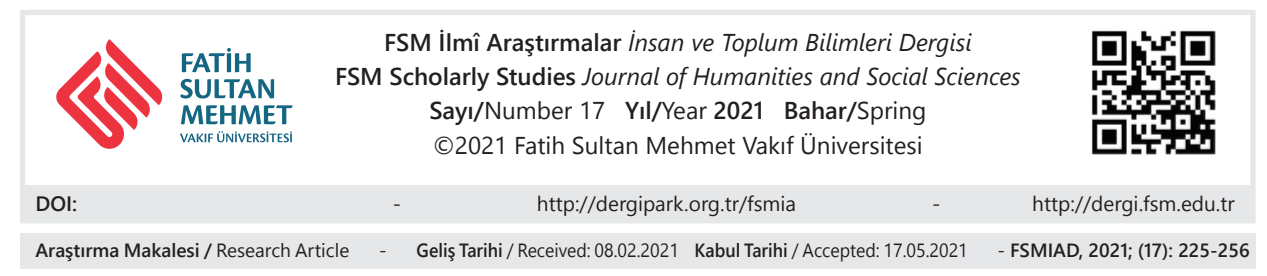

\title{
Osmanlı Mahalli Fuarcılığı Üzerine Bir Kesit: Sivas Hamidiye Sınaat ve Ziraat Sergisi
}

Hakan Asan*

\section{Öz}

Sivas Hamidiye Sinaat ve Ziraat Sergisi ulusal bir sergiden ziyade bölgesel veya mahalli olarak tabir edebileceğimiz bir organizasyondur. Sergi yerli üretimi sslah etmek, geliştirmek ve teşvik etmenin yanı sıra bölgesel ekonomiye katkı sağlamayı da hedeflemiştir. Osmanlı iktisat tarihinde ehemmiyetli bir mevzu olarak yerini alan sergide bölgenin ekonomik performansı, kaliteli üretim kapasitesi ve zenginlikleri temsil edilmiştir. Aynı zamanda sergi sonucunda ortaya çıkan problemlerin çözümü ve yerli ürünlerin yaygınlık kazanması konusunda gerçekçi önerilerin sunulmasını sağlamıştır. Çalışmada; Osmanlı Devleti'nin kurumları arasında gerçekleşen resmi yazışmalar ile dönemin basın hayatı üzerinden sergi süreci incelenmiştir. Ayrıca sergiden beklentiler, serginin hazırlık süreci ve açılışı ile sergide teşhir edilen ürünler değerlendirilmiştir.

Anahtar Kelimeler: Sergi, Sivas, sınaat, ziraat, II.Abdülhamit

\footnotetext{
* Dr., Dicle Üniversitesi Edebiyat Fakültesi Tarih Bölümü, Diyarbakır/Türkiye, hakan.asan@ dicle.edu.tr, orcid.org/0000-0002-8911-5247
} 


\title{
A Section on The Ottoman Regional Fairs: Sivas Hamidiye Industry and Agriculture Exhibition
}

\begin{abstract}
Sivas Hamidiye Industry and Agriculture Exhibition is a regional or local organization rather than a national exhibition. The exhibition aims to improve, develop and encourage domestic production as well as contribute to the regional economy. The economic performance, quality production capacity and richness of the region were represented in the exhibition, which took its place as an important subject in the history of Ottoman economy. At the same time, it ensured that realistic suggestions were presented regarding the solution of the problems that emerged as a result of the exhibition and the prevalence of domestic products. In the study; The exhibition process was examined through the official correspondence between the institutions of the Ottoman Empire and the press life of the period. In addition, expectations from the exhibition, the preparation process and opening of the exhibition, and the products displayed in the exhibition were evaluated.
\end{abstract}

Keywords: Exhibition, Sivas, industry, agriculture, II.Abdulhamit 


\section{Giriş}

Sergi; tanıtmak ve satış yapmak amacıyla bir ülkenin veya çeşitli ülkelerin ziraat, sanayi, el sanatları ve güzel sanatlar alanında ortaya koyduğu ürünlerin teşhir edildiği mekânlardır. ${ }^{1}$ Ayrıca bölgesel, ulusal veya uluslararası düzeydeki organizasyonlardır. Osmanlı belgelerinde zaman zaman "meşher"” kelimesiyle de ifade olunan ve günümüz fuarlarına karşılık gelen sergiler, klasik dönem panayırlarından farklılık arz etmektedir. ${ }^{3}$ Sergiciliğin kökenleri ticaret tarihinin ilk dönemlerine kadar uzatılabilmektedir. ${ }^{4}$ Ayrıca Olimpiyat oyunlarının dahi sergiciliğin ilkel bir geçmişi olduğu ifade edilmektedir. Selçuklular ve Osmanlı Devleti’nde ise ticaretin döndüğü pazarların da bir nevi sergiciliğin geçmişi olduğu belirtilmektedir. ${ }^{5}$

Sanayi devrimi sonrasında yaşanan gelişmelerle birlikte dünya ölçeğinde üretim artmış, ticaret gelişmiş, pazar ve ham madde ihtiyacı hâsıl olmuştur. Bunun sonucunda başlangıçta ulusal olarak gerçekleşen sergiler, 19. yüzyılın ikinci yarısından itibaren uluslararası olarak organize edilmiştir. Bu sergiler ülkelerin tarım, sanayi, bilim ve teknoloji alanlarındaki gelişme ve yeniliklerini tanıtmak amacını taşımıştır. ${ }^{6}$ Bunun yanı sıra devletlerin birbirini tanıması ve siyasi ilişki kurmasında da vazife görmüştür. Modern anlamda kabul edilen ilk uluslararası sergi 1851 tarihinde Londra' da açılmıştır. ${ }^{7}$ Osmanlı Devleti söz konusu sergiye katılım sağladığı gibi bu süreçten sonra düzenlenen uluslararası sergilerin birçoğuna da iştirak etmiştir. Böylece kendine has özellikleri yansıtan ürünleri teşhir edebilmiş, ziraat ve sanayi alanında gerçekleştirdiği üretimi de tanıtabilmiştir.

1 Ayhan Öney, İktisadi ve Ticari Terimler Sözlüğ̈̈, Ankara, Turhan Kitabevi, 1978, s. 274; İlhan Ayverdi, Misalli Büyük Türkçe Sözlük, İstanbul, Kubbealtı Yayınları, 2011, s. 1088.

2 BOA. İ.DH. 1410/20 1321 Ra. 05/01 Haziran 1903.

3 Ercüment Balcı, "Birinci Dünya Savaşı Yıllarında Batı Anadolu'da Mahalli Bir Fuar: Biga Sanayi ve Zirai Ürünler Sergisi (7 Eylül-7 Kasım 1916)”, Türk Dünyası Araştırmaları, S. 146, 2003, s. 86.

4 Gökhan Akçura, Türkiye Sergicilik ve Fuarcılık Tarihi, İstanbul, Tarih Vakfı Yayınevi, 2009, s. 13.

5 Sivas Vilayet Salnamesi, Sivas, Sivas Vilayet Matbaas1, Def'a 16, 1321, s. 229.

6 Gökhan Akçura, a.g.e., s. 20; Kenan Demir, “Sergi-i Umumi-i Osmani’nin (1863) Açılış1 ve Sergi'nin Duyurulmasında Gazetelerin Rolü”, Fırat Üniversitesi Sosyal Bilimler Dergisi, C. 28, S. 1, 2018, s. 155-156.

7 Söz konusu serginin öncesinde; 1699 ve 1789 tarihlerinde Paris’te, 1820'de Belçika'da, 1834'de Berlin'de ve 1835 'de Viyana'da ulusal nitelikli sergiler faaliyet göstermiştir. 1851 Londra sergisi ise devletlerarası bir sergi özelliği taşımıştır. Bknz; Kadri, "Tarih-i Sergi-yi Ber-Vech-i Umumi”, Местиа-i Fünun, No: 9, İstanbul, Cemiyet-i İlmiye-i Osmaniye, 1279, s. 386-387. 
Bu durum siyasi ve kültürel bağlamda da Osmanlı Devleti açısından önem arz etmiştir. ${ }^{8}$ Avrupa'da sergiler yaygınlaşınca Sultan Abdülaziz bir benzerinin İstanbul'da açılmasına karar vermiş; 1862'de başlayan hazırlıkların sonucunda 28 Şubat 1863 tarihinde Sultanahmet Meydanı'nda uluslararası düzeyde bir sergi açılmıştır. ${ }^{9}$ Bunun üzerine bu tarz sergilerin birkaç yılda bir olmak üzere tekrarının yapılması hatta İstanbul' dan başka diğer vilayetlerde de gerçekleştirilmesi gerektiği görüşü ağır basmıştır. ${ }^{10}$ Sergiler, pazar ve panayırların gelişmiş evresini ifade etmekte ve günümüzdeki fuarların özelliğini taşımaktadır.

Osmanlı vilayetlerinde düzenlenen mahalli sergilerin dünyaya açılma ve yaşanan gelişmeleri diğer ülkelere tanıtma gibi bir amacı bulunmamaktadır. Bu sergiler ile yerli üretim teşvik edilmek istenmiş ve yerli üretiminin rağbet görmesi hedeflenmiştir. İncelenen sergiler için ifade edilen "mahalli" kavramı arşiv belgeleri ve basında iki farklı anlamda kullanılmıştır. Birincisi; Osmanlı Devleti’nde üretilen veya yetiştirilen yerli ürünleri tanımlamak amacıyla ifade edilmiştir. İkincisinde ise serginin düzenlendiği vilayete ait mahsul, mamul ve eşyalar ifade edilirken bölgesel anlamında kullanılmıştır. Serginin düzenlenmesi aşamasında ve sergi sürecinde bu ifadeye uygun hareket edildiği görülmektedir. ${ }^{11}$ Osmanlı mahalli sergiciliği II. Abdülhamit döneminde ve 1901 tarihinde Konya Hal1-Kilim Sergisi ile başlamaktadır. Sivas Sergisi ise Osmanlı Devleti'nde düzenlenen ikinci mahalli sergilerindendir. Bu süreçte Sivas Sergisi ile birlikte İzmir ve Halep sergileri de düzenlenmiş ve Osmanlı sergiciliğinde ulaşılan ihtisaslaşma sü-

8 Semra Germaner, “Osmanlı İmparatorluğu'nun Uluslararası Sergilere Katılımı ve Kültürel Sonuçları”, Tarih ve Toplum Dergisi, S. 95, 1991, s. 33-40; Osmanlı Devleti, bunu takip eden y1llarda 1855 Paris, 1862 Londra, 1867 Paris, 1873 Viyana, 1889 Paris, 1893 Chicago, 1900 Paris sergilerine iştirak etmiştir. Haluk Kanca, "XIX. Yüzyılın İkinci Yarısında Uluslararası Osmanlı Fuarı: 1863 Sergi-i Umumi-i Osmani”, Muhasebe ve Finans Tarihi Araştırmaları Dergisi, S. 5, 2013, s. 162; Aziz Tekdemir, "1867 Paris Sergisi ve Sultan Abdülaziz’in Sergiyi Ziyareti”, Trakya Üniversitesi Edebiyat Fakültesi Dergisi, C. 3, S. 6, 2013, s. 1-2; Yeşim Duygu Ergüney - Nuran Kara Pilehvarian, “On Dokuzuncu Yüzyılda Dünya Fuarlarında Osmanlı Temsiliyeti”, Megaron, C. 10, S. 2, 2015, s. 227-239.

9 Münif, “Sergi-i Umumi Osmaniyeden Vuku-1 Küşadı”, Mecmua-i Fünun, No: 9, İstanbul, Cemiyet-i İlmiye-i Osmaniye, 1279, s. 362; Rifat Önsoy, “Osmanlı İmparatorluğunun Katıldığ İlk Uluslararası Sergiler ve Sergi-i Umumi Osmani (1863 İstanbul Sergisi)”, Belleten, C. 47, S. 185, 1983, s. 195-235; Ercüment Balc1, "İstanbul'un İlk Büyük Uluslararas1 Fuar1: Sergi-i Umumî-i Osmanî (1863)”, Antikçağ’dan XXI. Yüzyıla Büyük İstanbul Tarihi, C. IV, İstanbul, İstanbul BB. Kültür Yayınları, 2015, s. 231.

10 Kadri, "Sergi-i Umumi-i Osmanî”, Mecmua-i Fünun, No: 10, İstanbul, Cemiyet-i İlmiye-i Osmaniye, 1279, s. 430-434.

11 İkdam Gazetesi, No: 3316, 1321 C. 22/14 Eylül 1903, s. 2; Tercümanı Hakikat Gazetesi, No: 2897-8087, 1321 Ş. 6/27 Ekim 1903, s. 2 BOA. İ..DH. 1412/28 1321 Ca. 17/11 Ağustos 1903. 
reci etkisini göstermiştir. Osmanlı sanayisini geliştirme, yerli ziraat ve sanayiyi destekleme kararlılığını ortaya koyan mahalli sergiler Osmanlı Devleti’nin gelişme amaciyla gösterdiği çabanın doğal bir ürünüdür.

\section{Osmanlı Mahalli Sergiciliğ i}

Düzenlenen mahalli sergilerin birçok hedefi bulunmaktadır. Bu sergiler ile mahalli ziraat ve sanayinin sslah edilmesi, dönemin şartlarına uygun bir hale getirilmesi ${ }^{12}$ ve geliştirilmesi hedeflenmiştir. ${ }^{13}$ Avrupa menşeli ürünlerin yerine yerli ürünlerin teşvik edilmesi, yaygınlık kazandırılması ve rağbet görmesinin sağlanması da amaçlanmıştır. ${ }^{14}$ Ayrıca yeni icat ve buluşların ortaya çıkarılmasına yönelik amaçları da bulunmaktadır. ${ }^{15}$ Bununla birlikte vilayetler arasında ilişkinin arttırılması, ticaretin geliştirilmesi ve tüccarlık mesleğinin itibar kazanması da hedeflenmiştir. ${ }^{16}$ Ayrıca imalat sektöründe yaşanan problem ve eksikliklere dikkat çekilmek istenmiş, çözüm yollarının bulunması hedeflenmiş ${ }^{17}$ ve bölgesel ekonominin geliştirilmesi de amaçlanmıştır. ${ }^{18}$

Osmanlı mahalli sergiciliğinin başlangıcı kabul edilen Konya Halı-Kilim Sergisi'nin hazırlık çalışmaları yaklaşık iki yıl öncesinden başlamıştır. Konya Valisi Mehmet Ferit Paşa nezaretinde komisyon kurulmuş ve serginin işleyişi ile düzeni hakkında on sekiz maddelik nizamname hazırlanmıştır. ${ }^{19}$ Söz konusu sergi Konya'daki sanayi faaliyetlerini teşvik etmek ve halıcılık sanatının ilerlemesine katkı sunmak amacıyla 5 Mayıs 1901 tarihinde açılmıştır. İplik, yün ve pamuktan imal edilmiş olan her türlü halı, kilim, seccade, perde ve cicim ile çeşitli döşemelik kumaşların teşhir edildiği söz konusu sergi, bu anlamdaki Osmanlı vilayetlerinde düzenlenen ilk sergi olarak kabul edilmiştir. ${ }^{20}$ Serginin başarılı bir surette gerçekleşmesi, birçok katılımcının ürünlerini teşhir etmesi, ziyaretçilerin ilgi ve alakas1 serginin etkisini arttırmıştır. Nitekim Konya'daki sergi öncü bir sergi özelliği

12 BOA. Y..A...HUS. 456/4 1321 C. 10/3 Eylül 1903.

13 BOA. BEO 2087/156507 1321 Ra. 13/9 Haziran 1903.

14 İkdam Gazetesi, No: 3340, 1321 R. 16/8 Ekim 1903, s. 2.

15 BOA. İ.DH. 1410/20 1321 Ra. 05/01 Haziran 1903.

16 Tercümanı Hakikat Gazetesi, No: 2897-8087, 1321 Ş. 6/27 Ekim 1903, s. 2.

17 İkdam Gazetesi, No: 3340, 1321 R. 16/8 Ekim 1903, s. 2.

18 Sivas Vilayet Salnamesi, Def'a 16, 1321, s. 227;

19 Hüseyin Muşmal, "1901 Yılında Konya'da Açılan Halı-Kilim Sergisi ve 1899 Tarihli Sergi Talimatnamesi”, I. Uluslararası Türk El Dokumaları Kongresi Bildirileri, Konya, S.Ü. Selçuklu Araştırmaları Merkezi Başkanlığı Yayınları, ed. Ahmet Aytaç, 2007, s. 247; BOA. İ.DH. 1377/20 1318 Ca. 7/1 Eylül 1900; İkdam Gazetesi, No: 2464, 1319 M. 15/5 May1s 1901, s. 2.

20 BOA. BEO 2081/156025 1321 Ra. 4/31 May1s 1903; İkdam Gazetesi, No: 2475, 1319 M. 26/16 May1s 1901, s. 1; Sabah Gazetesi, No: 6074, 1324 B. 16/4 Eylül 1906, s. 2. 
göstermiş ve kendisinden sonra düzenlenecek mahalli sergiler tarafından örnek alınmıştır. ${ }^{21}$ Konya Hal1-Kilim Sergisi'nin örnek alınarak daha kapsamlı bir surette gerçekleştirilen sergiler 1903 yılında açılmıştır.

Osmanlı mahalli sergiciliğinin ilklerinden olan Halep Mahsulat ve Mamulat Sergisi'nin hazırlık sürecinde teşhir edilecek ürünlerin belirlenmesi, bu ürünlerin kabul edilmesi ve serginin düzenli bir surette gerçekleşmesi amacıyla Halep Valisi Mehmet Enis Paşa nezaretinde komisyon kurulmuştur. ${ }^{22}$ İlerleyen süreçte söz konusu komisyonda görevli kişilere ilaveten Vilayet Orman Müfettişi Maksut Bey, Numune Çiftliği Müdür Muavini Hamdi Bey, Vilayet Baytarı Civani Efendi ile vilayet memurlarından Şekip Bey aza tayin edilmiştir. ${ }^{23}$ Bu sergi hakkında on sekiz maddelik nizamname sergi komisyonu tarafından hazırlanmış ve Halep İdare Meclisi'nin onayına sunulmuştur. ${ }^{24}$ Buna göre Osmanlı Devleti'nde üretilen veya yetiştirilen ziraat ve sanayi alanındaki her çeşit mamulat, mahsulat, mensucat, hububat ile süs eşyalarının sergiye kabul edilmesine karar verilmiştir. ${ }^{25}$ Bununla birlikte Osmanlı ziraatına uygun yeni usul çiftçilik aletlerinin de Avrupa'dan getirilmesi ve teşhir edilmesi uygun görülmüştür. Bu ise ziraat aletlerinin değerlendirilmesi, mukayese edilmesi ve çiftçilik mesleğinde ilerlemeye katkı sunması düşüncesiyle gerçekleştirilmiştir. Bu düşünce doğrultusunda Avrupa'dan birçok orak makinesi, iki adet pulluk ile üç adet Alman ve Amerikan sapanı satın alınmış ve sergide teşhir edilmiştir. Halep’te açılan bu sergi başarryla maksadına hâsıl olmuştur. ${ }^{26}$ Halep Mahsulat ve Mamulat Sergisi, Halep'in Selimiye mevkiinde bulunan Halep İdadi Mektebi'nde 14 Ağustos 1903 günü açılmıştır. ${ }^{27}$ Halep Sergisi'nin resmi açılışı ise II. Abdülhamit'in tahta çıkış yıl dönümüne rastlayan 1 Eylül 1903 tarihinde gerçekleştirilmiştir. ${ }^{28}$ Ziyaretçilerin

21 Sivas Vilayet Salnamesi, Def'a 16, 1321, s. 227-232; İkdam Gazetesi, No: 2476, 1319 M. 27/17 May1s 1901, s. 1; İkdam Gazetesi, No: 2478, 1319 M. 29/19 May1s 1901, s. 1.

22 İkdam Gazetesi, No: 3200, 1321 S. 13/11 Mayıs 1903, s. 2.

23 İkdam Gazetesi, No: 3218, 1321 Ra. 2/29 May1s 1903, s. 2.

24 Tercümanı Hakikat Gazetesi, No: 2748-7948, 1321 S. 4/8 Haziran 1903, s. 3.

25 Sabah Gazetesi, No: 4890, 1321 Ra. 12/8 Haziran 1903, s. 2; İkdam Gazetesi, No: 3228, 1321 Ra. 12/8 Haziran 1903, s. 2.

26 BOA. BEO 2106/157904 1321 R. 8/4 Temmuz 1903; BOA. BEO 2131/159805 $1321 \mathrm{Ca} .10 / 4$ Ağustos 1903; BOA. Y..A...HUS 454/126 1321 Ca. 28/22 Ağustos 1903; İkdam Gazetesi, No: 3284, 1321 Ca. 9/3 Ağustos 1903, s. 2; Sabah Gazetesi, No: 4932, 1321 R. 24/20 Haziran 1903, s. 2.

27 İkdam Gazetesi, No: 3307, 1321 C. $2 / 26$ Ağustos 1903, s. 2; İkdam Gazetesi, No: 3309, 1321 C. 4/28 Ağustos 1903, s. 2.

28 Sabah Gazetesi, No: 4977, 1321 C. 11/3 Eylül 1903, s. 1; BOA. MF. MKT 730/22 1321 C. 1/25 Ağustos 1903. 
memnuniyetini sağlamak ve sergiye katılımı arttırmak amacıyla sergi programı hazırlanmıştır. Söz konusu programda özellikle eğlencelere önem verildiği görülmektedir. Bu amaçla sergi süresince meç oyunları, pehlivan güreşleri, jimnastik çalışmaları, at ve deve üzerinde gerçekleştirilen oyunlar, balon uçurma şenlikleri, bisiklet talimleri, semah gösterileri, çalgı eğlenceleri ve tiyatro oyunları icra edilmiştir. ${ }^{29} \mathrm{Bu}$ mahsulat ve mamulat sergisinde Halep Vilayeti’nin zirai ve sanayi zenginlikleri temsil edilmiştir.

II. Abdülhamit'in tahta çıkış yıl dönümünde tertip edilen diğer bir mahalli sergi ise İzmir Ticaret ve Sanayi Sergisi'dir. ${ }^{30}$ Serginin amacı; tohumların 1slah edilmesi, tohum çeşitliliğinin sağlanması ve zirai verimin arttırılmasıdır. Ayrıca Osmanlı dokuma ve imalat sektöründe gelişme sağlanması da hedeflenmiştir. Bununla birlikte devletin üretim ihtiyacının karşılanması ve ahalinin de mahalli ürünlere rağbet etmesi amaçlanmıştır. Ayrıca ticarette yeni imkanların ortaya çıkması ve ticaretteki ilerlemeye katkı sunması da beklenmiştir. ${ }^{31}$ İzmir Sergisi'nin gerçekleşmesi amacıyla gerekli hazırlıklar yapılmış, İzmir Belediye Reisi Eşref Paşa nezaretinde sergi komisyonu kurulmuş ve komisyon üyeleri de vilayet idare meclisi tarafından onaylanmıştır. Söz konusu komisyon Eşref Paşa'nın yanı sıra Ticaret Odası Reisi Hacı Davut Ferkof Efendi, Kitapçı Ahmet Sabri Efendi, Hristaki Efendi Atnaşola ${ }^{32}$, Ispartal1-zade Nakfur Efendi, Belediye Azas1 Cemal Bey, Bezzaz Hac1 Osman Efendi, Akarcalı Hac1 Yahya Efendi ${ }^{33}$ ve İstenidis Efendi tarafindan oluşmaktadır. ${ }^{34}$ Sergi komisyonunda yerel yetkililerin

29 İkdam Gazetesi, No: 3307, 1321 C. $2 / 26$ Ağustos 1903, s. 2; İkdam Gazetesi, No: 3309, 1321 C. 4/28 Ağustos 1903, s. 2.

30 İzmir Ticaret ve Sanayi Sergisi, arşiv belgeleri ve gazetelerde, aynı zamanda mahalli mahsulat ve mamulat sergisi ile ziraat ve sınaat sergisi olarak da ifade edilmiştir. İkdam Gazetesi, No: 3177, 1321 M. 20/18 Nisan 1903, s. 2; İkdam Gazetesi, No: 3301, 1321 Ca. 26/20 Ağustos 1903, s. 2; Sabah Gazetesi, No: 4930, 1321 R. 22/18 Temmuz 1903, s. 2.

31 Sabah Gazetesi, No: 4915, 1321 R. 7/3 Temmuz 1903, s. 3.

32 Fabrikatör olması sebebiyle komisyon üyeliğine sonradan kabul edilmiştir. Tercümanı Hakikat Gazetesi, No: 2793-7993, 1321 R. 29/25 Temmuz 1903, s. 2.

33 Kendisi İzmirli halı tüccarlarının önde gelenlerindedir. Halı, kilim ve bu gibi dokuma ürünlerinin değerini anlayabilmesi ve bu ürünlerde tecrübe sahibi olması sebebiyle sonradan komisyon üyeliğine kabul edilmiştir. Tercümanı Hakikat Gazetesi, No: 2793-7993, 1321 R. 29/25 Temmuz 1903, s. 2.

34 İkdam Gazetesi, No: 3177, 1321 M. 20/18 Nisan 1903, s. 2; Sabah Gazetesi, No: 4839, 1321 M. 20/18 Nisan 1903, s. 2; Tercümanı Hakikat Gazetesi, No: 2719-7919, 1321 S. 13/11 May1s 1903, s. 2; Tercüman1 Hakikat Gazetesi, No: 2668-7868, 1321 M. 22/20 Nisan 1903, s. 2; Tercümanı Hakikat Gazetesi, No: 2780-7980, 1321 R. 7/3 Temmuz 1903, s. 3; Sabah Gazetesi, No: 4969, 1321 C. $3 / 26$ Ağustos 1903, s. 2. 
yanı sıra muhtelif meslek guruplarının önde gelenleri de bulunmaktadır. Ayrıca İzmir'de teşkil edilen sergi komisyonun yanı sıra vilayete bağlı sancak ve kazalarda da uygun kişilerden ayrı ayrı komisyonlar kurulmuştur. Merkezi komisyonun birer şubesi gibi faaliyet gösteren söz konusu komisyonlar merkezdeki komisyon ile sürekli iletişim halinde olacaklardır. ${ }^{35}$ Sergide eşya ve mahsulat teşhir edenler arasında başarılı bulunanlara mükafat verilecektir. Bu süreçte "Sergi heyeti nezdinde ecnebi eşyast ile rekabet edecek durumda veya derecede bulunan eşyalar özellikle takdire mazhar olacaktır." ${ }^{36}$ Açılış töreni Aydın Valisi Kâmil Paşa nezaretinde ve Hamidiye Sanayi Mektebi'nin iç bölümünde gerçekleştirilmiştir. ${ }^{37}$ Kamil Paşa tarafından 1 Eylül 1903 tarihinde Dahiliye Nezareti'ne gönderilen yazıda; mahalli ziraat ve sanayinin gelişme göstermesi ve ilerleme sağlaması maksadıyla bu vilayet dahilinde padişahın iradesiyle düzenlenmesi istenilen serginin gerçekleştirildiği bildirilmiştir. ${ }^{38}$ Söz konusu sergide Osmanlı mamulü ve mahsulü ürünler mektebin yedi farklı salonunda teşhir edilmiştir. Birinci salonda Hamidiye Sanayi Mektebi ile Navarra ve Mafaka fabrikalarının ürünleri sergilenmiştir. İkinci salonda teşhir edilmiş olan eşyalar daha güzel ve mükemmeldir. Burada ipek ve yünden imal edilmiş muhtelif halılar mevcuttur. Ayrıca sırma ile işlenmiş mendil, hamam takımı, peşkir ile İzmir, Dersaadet ve Anadolu'nun muhtelif sanayisine ait yün ürünleri de teşhir edilmiştir. Üçüncü salonda dahi yün kilimleri mevcuttur. Bunların yanı sıra çorap, fanila, kaytan, at ve deve eyerleri, harar, ip ve Atnaşola Efendilerin fabrikasına ait ürünler sergilenmiştir Serginin en büyük kısmını oluşturan dördüncü salonda ise Hamidiye Sanayi Mektebi'nin mamulatı teşhir edilmiştir. Söz konusu ürünler güzel olduğu gibi fiyat bakımından da uygundur. Gayet zarif ve nefis ipek, yün ve pamuklu kumaşlarla peşkir, hamam takımı, ziraat aleti, hava gazı feneri ve eyer gibi daha birçok sanayi mamulatı burada yer almıştır. Beşinci salonda Atnaşola Biraderlerin kâğıt mamulatı ile Denizli'de tesis edilmiş bir fabrikanın ürünleri sergilenmiştir. Altıncı salonda sabun ve şekerciliğe ait mamulat mevcuttur. Son olarak yedinci salonda ise sepet, kundura, testi, çanak, çömlek ve emsali mamulat teşhir edilmiştir. Bu anlamda vilayet dahilinde ilk defa gerçekleştirilen İzmir Ticaret ve Sanayi Sergisi, muvaffakiyete mazhar olmuş, takdir kazanmış, dikkat çekmiş ve başarıyla gerçekleşmiş bir organizasyondur. ${ }^{39}$

35 İkdam Gazetesi, No: 3200, 1321 S. 13/11 May1s 1903, s. 2.

36 Sabah Gazetesi, No: 4974, 1321 C. 8/31 Ağustos 1903, s. 2.

37 BOA. Y..PRK.ASK. 202/104 1321 C. 8/1 Eylül 1903; Sabah Gazetesi, No: 4977, 1321 C. 11/3 Eylül 1903, s. 1; Sabah Gazetesi, No: 4979, 1321 C. 13/5 Eylül 1903, s. 2.

38 BOA. Y..A...HUS. 456/4 1321 C. 10/3 Eylül 1903.

39 Sabah Gazetesi, No: 4979, 1321 C. 13/5 Eylül 1903, s. 3. 


\section{Sivas Sergisinin Amacı}

II. Abdülhamit'in tahta çıkış yıl dönümünde açılan ve Osmanlı bölgesel sergiciliği bağlamında başarılı bir şekilde gerçekleşen mahalli sergilerden biri de Sivas Hamidiye Sinaat ve Ziraat Sergisi' dir. Sivas Sergisi'nin düzenlenme amac1; ziraat ve sanayinin ıslah edilmesi ve geliştirilmesinin sağlanmasıdır. ${ }^{40}$ Ayrıca tüccarlar arasındaki iletişimin arttırılması ve Avrupa menşeli ürünlerin yerine yerli ürünlerin teşvik edilmesi ve yaygınlık kazandırılması amaçlanmıştır. Bununla birlikte sınata kabiliyeti, hüneri ve gayreti bulunan fakat ismi duyulmamış kişilerin bilinirliğinin sağlanması da hedeflenmiştir. ${ }^{41}$ Ayrıca bölgesel ekonominin geliştirilmesi amaçlanmıştır. ${ }^{42}$

Sivas Sergisinde teşhir edilmesi planlanan eşya ve mahsuller arasında herhangi bir ayrım yapılmaması amaçlanmış ve sergi kapsamının geniş tutulması hedeflenmiştir. Örneğin Sivas Vilayeti'nden Kastamonu Vilayeti'ne sergi konusunda gönderilen talimatnamede; "sergiye yerden çıkan her nevi mahsulat gönderilebiliyor. Belki tarladaki patates ile pancarı sergiye koymaktan ne çıkar mütalaasında bulunanlar olur. Halbuki iki mahal-i mahsulatı arasında keşif ortaya çıkabilir ve faydal gelişmeler yaşanabilir. Mahsuller arasında nispet, müddet-i idrak, fiyat, lezzet gibi daha birçok cihetlerden fark bulunur. Iş̧te bu farkı ortaya çıkarma ve bundan bir fikr-i ticari ve bir ilm-i zirai edinmek sergilerde mümkün olur. Hülasa şeraiti daire-i şümulü geniş tutmanın faydaları muhakkak vardır" denilmektedir. ${ }^{43} \mathrm{Bu}$ sergide sadece bir çeşit eşya veya mahsul teşhir edilmemiştir. Burada Osmanlı Devleti'nde üretilmesi veya yetiştirilmesi şartıyla her türlü eşya ve mahsul sergilenmiştir. Sadece Osmanlı Devleti'nde istifade edilen ziraat aletleri hangi devlette imal edilirse edilsin bu sergide yerini almıştır. Bu ise dönemin ihtiyacına binaen yapılmış ve bunun da faydası görülmüştür. ${ }^{44}$ Bununla birlikte sergide teşhir edilecek eşyanın büyük bir kısmının Sivas Vilayeti’nin eşya ve mahsulâtından olması planlanmıştır.

40 BOA. BEO 2081/156025 1321 Ra. 4/31 Mayıs 1903, s. 2; Sabah Gazetesi, No: 4883, 1321 Ra. 5/1 Haziran 1903, s. 1.

41 İkdam Gazetesi, No: 3245, 1321 Ra. 29/25 Haziran 1903, s. 3; Sabah Gazetesi, No: 4907, 1321 Ra. 29/25 Haziran 1903, s. 2.

42 Sivas Vilayet Salnamesi, Def'a 16, 1321, s. 227; İkdam Gazetesi, No: 3340, 1321 R. 16/8 Ekim 1903, s. 2.

43 Sabah Gazetesi, No: 4907, 1321 Ra. 29/25 Haziran 1903, s. 2.

44 Sivas Vilayet Salnamesi, Sivas, Sivas Vilayet Matbaası, Def'a 17, 1325, s. 238. 


\section{Sivas Sergisinin Hazırlık Dönemi}

Vali Reşit Akif Bey, Sivas Vilayeti'ne görevlendirildikten bir süre sonra burada bir sergi açılmasını kararlaştırmıştır. Fakat ortaya çıkan bazı problemler sebebiyle bu kararını ertelemek zorunda kalmıştır. İlerleyen süreçte Sadaret'ten gelen yazı ve II. Abdülhamit'in iradesi ile bazı vilayetlerde sergilerin düzenlenmesi istenmiştir. Söz konusu vilayetler arasında Sivas Vilayeti'nin de yer alması bir firsat niteliğinde görülmüştür. ${ }^{45}$ Ayrıca yaşanan bu gelişmeler üzerine Sivas ahali ve eşrafı memnuniyetlerini bildiren dilekçelerini yetkililere ulaştırmıştır. ${ }^{46}$ Planlanan serginin 1 Eylül 1903 'de ${ }^{47}$ yani II. Abdülhamit' in tahta çıkış yıl dönümünde açılması kararlaştırılmıştır. ${ }^{48}$ Sivas Sergisi'nin hazırlık çalışmaları söz konusu tarihten yaklaşık altı ay öncesinde başlamıştır. ${ }^{49}$ Öncelikle serginin nerede gerçekleşeceği konusunda hazırlık yapılmış ve bu konuda iki devlet binası ön plana çıkmıştır. Bunlardan birincisi Guraba Hastanesi'dir ve hazırlık çalışmalarının başlangıcında serginin bu hastanede tesis edilmesine karar verilmiştir. ${ }^{50}$ İkincisi ise yeni inşa edilen Hamidiye Sanayi Mektebi' dir. ${ }^{51}$ Sonrasında Hamidiye Sanayi Mektebi uygun bulunmuş ve sergi binası olarak tercih edilmiştir. Ayrıca Sivas Hükümet Konağı'ndan sergi binası olarak tercih edilen Hamidiye Sanayi Mektebi'ne giden yedi yüz metre uzunluğunda yeni bir cadde inşa edilmiştir. ${ }^{52}$

Sivas Sergisi'nin hazırlık aşamasında Osmanlı yerel sergiciliğinde daha öncesinde kazanılan tecrübeden istifade edilmiştir. Sivas Vilayeti'nden Sadarete gönderilen bir yazıda; muhtelif vilayetlerde açılacak sergilerde kabul edilmek üzere bir talimatnamenin düzenlendiği hakkında bir duyum alındığı belirtilmiş ve bunun da gerçekliği konusunda kendilerine bilgi verilmesi istenmiştir. ${ }^{53}$ Bunun

45 Sivas Vilayet Salnamesi, Def'a 16, 1321, s. 230.

46 Sabah Gazetesi, No: 4883, 1321 Ra. 5/1 Haziran 1903, s. 1.

47 II. Abdülhamit Rumi takvime göre 19 Ağustos 1292 (31 Ağustos 1876) tarihinde tahta ç1kmıştır. Sivas Sergisi de Rumi takvime göre 19 Ağustos 1319 (1 Eylül 1903) tarihinde açılmıştır. $\mathrm{Bu}$ tarih, II. Abdülhamit'in tahta çıkışının yirmi yedinci yıl dönümüdür.

48 Sivas Vilayet Salnamesi, Def'a 16, 1321, s. 230; Sabah Gazetesi, No: 4859, 1321 S. 10/8 May1s 1903, s. 1.

49 BOA. BEO 2046/153392 1321 M. 18/16 Nisan 1903.

50 İkdam Gazetesi, No: 3198, 1321 S. 10/8 Mayıs 1903, s 3; Sabah Gazetesi, No: 4859, 1321 S. 10/8 May1s 1903, s. 2.

51 Sivas Vilayet Salnamesi, Def'a 16, 1321, s. 230; İkdam Gazetesi, No: 3221, 1321 Ra. 5/1 Haziran 1903, s. 1.

52 Sabah Gazetesi, No: 4977, 1321 C. 11/3 Eylül 1903, s. 1; Tercümanı Hakikat Gazetesi, No: 2846-8046, 1321 C. 24/16 Eylül 1903, s. 2; İkdam Gazetesi, No: 3318, 1321 C. 24/16 Eylül 1903, s. 2.

53 BOA. BEO 2064/154788 1321 S. 12/10 Mayıs 1903. 
üzerine Sivas Vilayeti'ne de ulaştırılan söz konusu talimatname temel alınarak planlanan serginin esasları belirlenmiştir. Konya Hal1-Kilim Sergisi'ne ait talimatname örnek alınarak hazırlanmasına rağmen bundan daha kapsamlı bir nizamname Sivas Sergisi için hazırlanmıştır. ${ }^{54}$ Serginin tesis edilmesinde Vali Reşit Akif Bey gayretli bir çalışma gerçekleştirmiştir. ${ }^{55}$

Sivas Sergisi'nin hazırlık sürecinde Sivas Valisi Reşit Akif Bey başkanlığında sergi komisyonu kurulmuş ve sergi çalışmalarının bu komisyon tarafından idare edilmesi planlanmıştır. Söz konusu komisyon üyeleri şu kişilerden oluşmaktadır: ${ }^{56}$

Tablo 1: Sivas Sinaat ve Ziraat Sergisi Komisyonu

\begin{tabular}{|c|c|}
\hline Reis & Vali Reşit Akif Bey \\
\hline Aza & Sivas Furka Kumandanı Hulusi Paşa \\
\hline Aza & Hâkim Nazif Efendi \\
\hline Aza & Defi Muavini Aristidi Efendi \\
\hline Aza & Mektupçu Esat Raif Bey \\
\hline Aza & Maarif Müdürü Tahir Rüştü Efendi \\
\hline Aza & Orman Müfettişi Mehmet Hulusi Bey \\
\hline Aza & Meclis İdare Azası Haçator Efendi \\
\hline Aza & Kondüktör Sami Efendi \\
\hline Aza & Kondüktör Seropa Efendi \\
\hline Aza & Kılıççı Ali Efendi \\
\hline Aza & Makinist Mösyö Adolf \\
\hline Aza & Çilingir Hacı Osekhan Efendi \\
\hline Aza & Dökmeci Boşoğlu Karabet Ağa \\
\hline Aza & Kuyumcu Çamoğlu Serkis Ağa \\
\hline Aza & Bıçakçı Armenak Ağa \\
\hline Aza &
\end{tabular}

Sergi komisyonu haricinde planlanan her şube için ayrıca heyetler kurulmuştur. Bunlar; dokuma şubesi, hayvancılık ve dericilik şubesi, marangoz şubesi, ziraat şubesi ve maden şubesi heyetleridir. Ayrıca tertip ve tanzim heyeti, muhasebe heyeti, kayıt heyeti ve muhafaza heyeti de oluşturulmuştur. Bunların yanı sıra daire müdürü ve yardımcıları ile teşrifat memurları da belirlenmiştir. ${ }^{57}$

54 BOA. BEO 2081/156025 1321 Ra. 4/31 May1s 1903.

55 Sabah Gazetesi, No: 4967, 1321 C. 1/24 Ağustos 1903, s. 1.

56 Sivas Vilayet Salnamesi, Def'a 16,1321, s. 231-232.

57 Sivas Vilayet Salnamesi, Def'a 16, 1321, s. 231-234. 
Sivas'ta planlanan sergi için bütün Osmanlı vilayetlerine haber verilmiştir. Ayrıca Sivas Vilayeti'ne bağlı kazalar ile Konya, Ankara, Diyarbakır, Harput, Kastamonu ve daha birçok vilayet de düzenlenecek sergiye davet edilmiştir. ${ }^{58}$ Söz konusu davet yazıları ile çevre vilayetlerin düzenlenecek sergiye katılımı teşvik edilmiştir. Ayrıca çevre vilayetlerden eşya ve mahsulat gönderip gönderemeyeceklerini haber vermeleri, gönderecekler ise eşya ile mahsulün çeşit ve miktarını şimdiden telgrafla bildirmeleri ve gönderilecek eşyaların serginin açılış gününden bir ay öncesinde Sivas'a ulaştırmaları istenmiştir. ${ }^{59}$ Bununla birlikte sergide teşhir edilecek eşyanın büyük bir kısmının Sivas Vilayeti'ne ait ürünlere ayrılacağından Sivaslı sanatkârlardan en güzel eserlerini bu sergide teşhir etmeleri istenmiştir. ${ }^{60}$ Bunların yanı sıra Sivas'ta görev yapan memurlar ile Sivas ahalisi sergiciliğin önemi, gerekliliği ve faydası noktasında bilgilendirilmiş ve sergicilik konusunda teşvik edilmiştir. ${ }^{61}$ Bununla birlikte Orman, Maden ve Ziraat Nezareti tarafından yeni icat edilen ziraat aletleri teşhir amacıyla sergiye ulaştırılmıştır. ${ }^{62}$

\section{Sivas Serginin Nizamnamesi}

Sivas Vilayet merkezinde açılması kararlaştırılan Sınaat ve Ziraat Sergisi'ne mahsus yirmi maddelik bir nizamname hazırlanmış ve 12 Mayıs 1903 tarihinde Sadaret'e gönderilmiştir. ${ }^{63}$ Buna göre; Sinaat ve Ziraat Sergisi Padişah'ın cülusu devriyesine denk gelen günde yani 1 Eylül 1903 tarihinde açılacak ve 28 Ekim 1903 tarihine kadar devam edecektir. Osmanlı Devleti'nde yetiştirilmiş veya üretilmiş olmak şartıyla her çeşit ziraat mahsulü, dokuma mamulü, maden ve marangozluğa ait eşya ile muhtelif hayvan ve hayvancıllğa ait ürünler bu sergiye kabul edilecektir. Ayrıca Osmanlı Devleti'nde istifade edilen ziraat aletleri hangi devletin mamulâtından olursa olsun sergide yer alabilecektir.

Sergilenecek eşya beş ayrı bölümde teşhir edilecektir. Birinci bölüm dokuma ürünlerine ait olacaktır. Halı, kilim, perde, sicim, aba, şayak, keçe, çorap, şal, kuşak, her türlü yünlü kumaş, hamam takımı, manusa, tire dokuması, döşemelik kumaş, yazma, bez, şerit, kaytan, çamaşır kumaşı, çetari, ketari, ipekten mamul

58 BOA Y..A...HUS 446/66 1321 M. 20/18 Nisan 1903; Sabah Gazetesi, No: 4975, 1321 C. 9/1 Eylül 1903, s. 4.

59 İkdam Gazetesi, No: 3191, 1321 S. 4/2 May1s 1903, s. 2; İkdam Gazetesi, No: 3210, 1321 S. 23/21 Mayıs 1903, s. 2; Tercümanı Hakikat Gazetesi, No: 2710-7910, 1321 S. 4/2 Mayıs 1903, s. 1; Tercümanı Hakikat Gazetesi, No: 2717-7917, 1321 S. 11/9 Mayıs 1903, s. 2.

60 Sivas Vilayet Salnamesi, Def'a 16, 1321, s. 231.

61 Sivas Vilayet Salnamesi, Def'a 16, 1321, s. 228-229.

62 İkdam Gazetesi, No: 3309, 1321 C. 4/28 Ağustos 1903, s. 2.

63 BOA. BEO 2081/156025 1321 Ra. 4/31 May1s 1903, s. 2. 
elbise, çarşaf, mendil, kefiye, sırma ve ipekten işlemeli süsleme mamul ile kenevir mamulâtı bu bölümde yer alacaktır. İkinci bölüm maden mamulâtı ile ilgili olacaktır. Bu bölümde demir ve pirinç gibi çeşitli madenlerden imal edilmiş pulluk, sapan demiri, araba çemberi gibi ziraat aletleri, çelikten mamul araba yayı, çakı, bıçak, mikrâs, cerrahiye aleti ve marangozların kullandığı aletler burada teşhir edilecektir. Ayrıca altın ve gümüşle süslü kama, kılıç, gelebe, kantar, terazi, bakırdan mamul mutfak ve sofra aletleri, dökme şamdan, sigara tablası, altın, gümüş, yakut ve nikel sanatlı aletler de bu bölümde yer alacaktır. Üçüncü bölüm marangozluğa ait olacaktır. Fayton ve lando gibi arabalar, sslah veya icat edilmiş ziraat aletleri, arı kovanı, yayık, müzik aleti, baston, naleyn ve sepet bu bölümde yer alacaktır. Dördüncü bölüm ziraat mahsulâtı ile ilgili olacaktır. Teşhire uygun ${ }^{64}$ cinslerden olmak üzere buğday, arpa, mısır, darı, yulaf, çavdar, mercimek, nohut, fasulye, bakla, pirinç, çay, kuru meyve, reçel, şurup, hardaliye, bal, pekmez, üzümden mamul sucuk, pestil, yağ, peynir, sebze tohumu, sabun, halıc1lık ve dokumacılıkta kullanılan yerli boya çeşitleri bu bölümde yer alacaktır. Beşinci bölüm hayvancılık ve dericiliğe ait olacaktır. Her çeşit beygir, kısrak, inek, tosun, manda, deve, katır, koyun, keçi, av ve çoban köpeği, kaz, ördek, hindi, tavuk, horoz, güvercin gibi çeşitli hayvanlar ${ }^{65}$ ile kösele, vidala, meşin, sahtiyan, keçi ve deve derisi, telatin, güderi, deriden yapılmış cilt, tilki, sansar ve kurt gibi hayvanların derisinden imal edilen kürklü eşya veya post, pabuç, mest, terlik, her çeşit ayakkabı, araba koşum ve eyer takımı bu bölümde yer alacaktır.

Eşya teşhir etmek isteyen kişiler 7 Ağustos'a kadar merkezdeki sergi komisyonuna eşyalarını teslim edecektir. Sivas merkezinde bulunmayan kişiler ise 14 Ağustos'a kadar ikametlerinin bulunduğu belediye veya kaymakamlığa eşyalarını ulaştıracaktır. Vilayet merkezinin haricindeki belediye başkanı, kaymakam ve idare meclis üyeleri söz konusu kişilerden eşyaları teslim alabilecektir. Bu yetkililer teşhir edilecek eşyayı ücretini karşılayarak ve emniyetli bir şekilde merkez komisyonuna ulaştıracaktır. Eşya sahipleri kendi istemeleri durumunda eşyalarını bizzat ve vasitasız olarak merkezdeki sergi komisyonuna teslim edebilecektir. Eşyasını teslim eden kişilere resmiyet amacıyla ve eşyalarını teslim ettiğine dair bir makbuz verilecektir. Bu kişilerden eşya teslimi esnasında bazı isteklerde bu-

64 Sivas Vilayeti'nin haricindeki vilayetlerden gelecek hayvan ve ziraat hâsılatı teşhire layık ve uygun olması gerekmektedir. Buna rağmen Sivas Vilayeti dâhilinden gelen hâsılat ve eşyanın eksiği olur ise fazla olmamak şartıyla hepsinden birer kıyye numune olarak sergide teşhir edilecektir.

65 Sergiye gönderilecek hayvanlar için özel ahırlar olmadığından bunlar bizzat sahipleri tarafından muhafaza edilecek ve gündüzleri sergi dairesi civarında tahsis edilen alana taşınarak teşhir olunacaktır. 
lunulacaktır. Eşya sahipleri teşhir olunacak eşya ve mahsulât hakkında nerede, ne vakit ve kimin tarafından üretildiğini bildirecektir. Eşya ve ürün sahiplerinin isimleri teşhir olunan eşyasının üzerine arzu ve isteğine göre yazılacaktır. Bu sebeple isimlerini teşhir etmek isteyip istemediklerini yetkililere belirtecektir. Ayrıca gerçek isim, şöhret ve ikametgâhlarını da bildirecektir. Teşhir edeceği eşyayı satmayı arzu edenler mallarının fiyatı belirleyecek ve kayıt altına alınmasını sağlayacaktır. Sergi komisyonu tarafından teşhir olunacak eşya hakkında bilgilerin yer aldığı bir defter hazırlanacaktır. Teşhir edilen eşya sergi müddetince sigortalı olacaktır. Eşyanın zarar görmesine sebebiyet verenler sorumlu olacak ve zararı karşılayacaktır.

Sergide teşhir olunacak eşyadan teşhir ücreti veya başka bir isim altında herhangi bir ücret alınmayacaktır. Yalnız gerçekleştirilen satışlardan bir ücret istenecek, bu ise kuruşta bir para olacaktır. Ayrıca satılacak canlı hayvanlardan yüz kuruşa kadar olandan bir ücret alınmayacak ve bu miktardan sonra ise satış ücreti olarak her yüz kuruşta yirmi para alınacaktır. Serginin sonunda kalan eşyalar, satılan eşyaların bedelleri ve mükâfat evrakı komisyonda bulunan görevliler tarafindan sahiplerine teslim edilecektir. Gerçekleşen satışlardan sonra makbuzlar ve satış gelirleri komisyon tarafından tekrardan gözden geçirilerek hesaplanacaktır. Canlı hayvan ve aynı cinsten birçok emsali bulunan eşyaların satışı ne zaman gerçekleşirse gerçekleşsin serginin aç1lışından yirmi beş gün kadar teşhirde kalmaya devam edecek ve belirtilen sürenin sonunda alıcısına teslim edilecektir.

Sergi binasını ziyaret etmek isteyen kişiler giriş ücreti verecektir. Bu ücret on beş yaşından küçükler için yirmi para ve büyükler için ise bir kuruş olacaktır. Bizzat eşyasını sergide teşhir eden kişilere özel olarak ücretsiz giriş bileti sağlanacaktır. Sergi alanına girmek isteyen kadın ve erkekler için ayrı günler tahsis edilecektir. Sergi binası dâhilinde teşhir olunan eşya ve malların fotoğrafını çekmek kesinlikle yasak olacaktır. Serginin hatırası olması amaciyla imal ettirilen ipek mendiller bir ücret karşılığında satışa çıkarılacaktır.

Osmanlı Devleti'nde istifade edilecek ürün ve yeni icat edilmiş alet veya makine teşhir edenler komisyon tarafından ziraatın ilerlemesine yaptığı katkıdan dolayı takdir edilecektir. Bu kişilere duruma göre beş liradan elli liraya kadar mükâfat verilecektir. Ayrıca sergide teşhir ettiği eşya ile birincilik veya ikincilik kazananlara şahadetname ve takdirname verilecektir. Maddi mükâfat ve şahadetname ile takdir olunacak halı ve kilimlerin dokuma, üretim, nakış ve işlemesi dikkate alınacaktır. Söz konusu ürünlerde Avrupa tarzından ziyade şark usulüne muvafik olanlar tercih edilecektir. Bununla birlikte diğer dokuma ve mamulât için yalnız sanattaki mükemmeliyet dikkate alınacaktır. Ayrıca ziraat hâsılatı ve 
hayvanların tamamı sergiye kabul edilecek, özellikle dışarıdan getirilen damızlık hayvan ve zirai tohumlar ile iyi hayvan yetiştirmek konusunda çalışma yapanlar şahadetname almaya hak kazanacaktır. Halı, kilim ve keçe gibi tek parça eşya ile antika eser veya manzarayı içeren resim, tablo, model ve fotoğraflar teşhir amacıyla sergiye kabul edilecektir. Söz konusu eserlerden teşhir ücreti alınmadığ1 gibi başarılı bulunduğunda sahiplerine takdirname verilecektir.

Sergi komisyonu vilayetçe uygun görülen kişilerden oluşacak, mükâfat ve şahadetname ile takdir edilecek kişileri belirlemek için gerektiğinde tecrübeli-uzman kişilere müracaat edecektir. Söz konusu komisyon hazırlanan bu serginin gerçekleşmesinde yetkili olacak ve bu bağlamdaki gereklilikleri yerine getirecektir. Komisyon gerekli görmesi durumunda ve vilayet meclisinin kararıyla bu nizamnamenin bazı maddelerini iptal edebilecek veya değiştirilebilecektir. ${ }^{66}$

\section{Sivas Serginin Binası}

Serginin düzenlendiği Hamidiye Sanayi Mektebi, Kabak Yazısı isimli mevkide ve şehrin o dönemdeki uç noktası sayılabilecek muhteşem bir manzaraya sahip alana inşa edilmiştir. Söz konusu bina bu dönemde inşa edilmiş ve bu sebeple de mektebe dönemin Padişahı II. Abdülhamit'in ismi verilmiştir. ${ }^{67}$ Bununla birlikte serginin gerçekleştiği Hamidiye Sanayi Mektebi’nin birtakım eksiklikler sebebiyle henüz resmi açılışı gerçekleşmemiş ise de sergi sürecinden sonra eksiklikler tamamlanarak işlevine başlayacaktır. ${ }^{68}$ Sergi binasının doğu cephesi sahraya dönüktür ve beş kapısı bulunmaktır. Büyük kapı olarak adlandırılan giriş kapısı binanın tam ortasındadır. Bu kapıya iki taraftan sekiz kademeli yonma ve parlak taşlardan yapılmış iki merdivenden çıkılır. Merdivenin tırabzanlığında zarif oymalar ve yıldız nakışlı direkler bulunmaktadır. Söz konusu kapının üzerinde celi hat ile "Hamidiye Sinaat ve Ziraat Sergisi" yazılmış ve bu yazı ziyaretçilerin takdirini kazanmıştır. Diğer dört kapı ise binanın çıkıntılı köşelerinde yer almaktadır. Bu kapılara dahi yonma taştan yapılmış beşer kademeli merdivenler ile çıkılmaktadır. Söz konusu alanın kenarında demir parmaklıklar bulunur. Bu parmaklıklar ve direkler pek latif bir surette boyanmış ve koridorun girişi ise çimen ve çiçeklerle süslenerek düzenlenmiştir. Söz konusu merdivenlerin çevrelerine, arzu edenlerin kullanması amacıyla, numune çiftliğinden getirilen ziraat aletleri dizilmiştir. Köşelerdeki merdivenlerden çıkılınca yonma taşlarla döşenmiş ve iki

66 BOA. BEO 2081/156025 1321 Ra. 4/31 May1s 1903, s. 3.

67 İkdam Gazetesi, No: 3316, 1321 C. 22/14 Eylül 1903, s. 2.

68 Sabah Gazetesi, No: 4990, 1321 C. 24/16 Eylül 1903, s. 2-3; İkdam Gazetesi, No: 3318, 1321 C. 24/16 Eylül 1903, s. 2-3. 
taraftan merkez kapısında sona eren birer koridora varılmaktadır. ${ }^{69}$ Sergi binası tamamen halı, kilim ve kıymetli kumaşlar ile süslenmiştir. Sergi binasına büyük kapıdan girildikten sonra dört tarafa girişi bulunan ara bölüme ulaşılmaktadır. Giriş kapısına yakın bir oda vali ve mahiyetindekiler için tahsis edilmiştir. Sergi binasında teşhir salonlarının haricinde kabul salonu, muhasebe odası ve eşyaların muhafaza edildiği odalar da bulunmaktadır. ${ }^{70}$

Bu havalinin daha ilerisi ise Kabak Yazısı'nı teşkil eden geniş meydanlığa kadar uzanır. Binanın çevresinde bulanan araziye ağaçlar dikildiğinden mektep güzel bir manzaraya sahiptir. ${ }^{71}$ Serginin gerçekleşeceği bina ve bahçesinin yanı sıra binaya giden yeni bir cadde inşa edilmiştir. Hükümet konağından başlayıp sergi binasında sona eren ve sergi ile beraber aç1lışı gerçekleşen yeni cadde, serginin açılış gününe kadar hazır hale getirilmiştir. ${ }^{72}$ Söz konusu caddenin başlangıcında ise bir kemer bulunmaktadır. Serginin açılış gününde bu kemer, çiçek ve yapraklarla süslenmiştir. Caddenin iki tarafında birbirine yakın olarak dikilen telgraf direkleri zarif bir surette boyanmış ve bu direklere birçok sancak asılmıştır. Caddenin başlangıcında yer alan kemerin önünde iki süvari askeri nöbet tutar vaziyette beklemiştir. Ayrıca söz konusu caddenin sonuna kadar olan mesafede ve kısa aralıklarla piyade ve jandarma birlikleri sergi gününde hazır bulunmuştur. ${ }^{73}$

\section{Sivas Serginin Açılışı}

Sivas Hamidiye Sınaat ve Ziraat Sergisi'nin resmi açılışı planlanan tarihte yani II. Abdülhamit'in tahta çıkış yıl dönümünde gerçekleşmiştir. Sivas Valisi Reşit Akif Bey, 1 Eylül 1903 tarihinde, günün anlam ve önemine binaen Sivas Hükümet Konağı'nda tebrikleri kabul etmiştir. Saat yedi civarında, Vali Reşit Akif Bey, On Altıncı Fırka Kumandanı Ferik Hulusi Paşa, askeri ve mülki memurlar, ulema ve konsoloslar ile birlikte hükümet konağından serginin gerçekleştiği binaya geçmiştir. Sergi dairesi önünde bu heyeti çok fazla sayıda ahali, eşraf, esnaf, sergi katılımcısı, bando takımı ve bir bölük asker hazır olarak beklemiştir. Heyet binanın önüne geldiğinde bando takımı ve askerler tarafından kendilerine sayg1 gösterilmiştir. Sonrasında bu heyet, güzel bir surette süslenmiş kabul salonunda biraz istirahat etmiştir. Bundan sonra Vali, Fırka Kumandanı ve diğer yetkililer serginin gerçekleştiği binanın büyük kapısı önündeki meydanlığa teşrif

69 Tercümanı Hakikat Gazetesi, No: 2857-8057, 1321 B. 5/27 Eylül 1903, s. 3.

70 İkdam Gazetesi, No: 3316, 1321 C. 22/14 Eylül 1903, s. 2.

71 Tercümanı Hakikat Gazetesi, No: 2857-8057, 1321 B. 5/27 Eylül 1903, s. 3.

72 İkdam Gazetesi, No: 3316, 1321 C. 22/14 Eylül 1903, s. 2.

73 Tercümanı Hakikat Gazetesi, No: 2846-8046, 1321 C. 24/16 Eylül 1903, s. 2; İkdam Gazetesi, No: 3318, 1321 C. 24/16 Eylül 1903, s. 2. 
etmiştir. Bu esnada askeri bando tarafindan marş çalınmıştır. Bu marşın sonunda Vali Reşit Akif Bey tarafindan bir nutuk okunmuştur. ${ }^{74}$

Vali Reşit Akif Bey'in nutku "Rabbimiz Teâlâ ve Takaddüs Hazretleri ömür ve şevket-i velî bî-nimet-i azamîyi müzdâd ve firâvân buyursun" duasıly başlamış, padişah II. Abdülhamit'e övgü sözleriyle devam etmiştir. Sonrasında; Padişah tarafından emir buyrulması üzerine Sivas'ta teşekkülüne bir süredir çalışılan Hamidiye Sınaat ve Ziraat Sergisi'nin resmi açılışını birçok vilayetten evvel gerçekleştirdiklerini ve özel olarak padişahın cülus gününe denk getirdiklerini bildirmiştir. Bu açıdan bahtiyar olduğunu ve bu önemli günde gerçekleşen serginin pek parlak bir netice ile sonuçlanacağını belirtmiştir. Ayrıca Sivas'ta bu anlamda bir serginin ilk defa gerçekleştiğini hatırlatmıştır.

Vali Reşit Akif Bey, her şeyin başlangıcında bazı noksanlıklar olabileceğini, bu açıdan düzenlenen sergide de küçük eksiklikler bulunduğunu, buna rağmen ortaya çıkan gelişmeden iftihar ettiğini bildirmiştir. Bu serginin mükemmeliyet ve zarafet arz ettiğini, çeşitli ürünlerin teşhir edildiğini, serginin gerçekleşmesinde sarf edilen emeğin önemli olduğunu belirtmiştir. Vali'ye göre; Osmanlı Devleti’ndeki iktisadi ilerlemeye en büyük katkı dönemin Padişahı tarafından sağlanmıştır. Çünkü burada teşhir edilecek eşya ve mahsul Osmanlı Devleti'nin kendi ürünleridir. Bunun ise II. Abdülhamit' in sanayi, sanat ve ziraat alanlarında sağladığı ilerlemenin doğal bir neticesi olduğunu belirtmiştir. Bu serginin de söz konusu ilerlemeye katkı yapacağını bildirmiştir. Ayrıca serginin şimdiden gördüğü rağbeti sevinçle karşıladığını ve hedefine ulaşacağından şüphe duymadığını ifade etmiştir. Bunun yanı sıra yaşananları güzel ve etkili bir başlangıç olarak gördüğünü belirtmiştir.

Vali Reşit Akif Bey, nutkunun son kısmını ise teşekküre ayırmıştır. Öncelikle serginin düzenlenmesinde emeği geçen merkez ve sancaklardaki görevlilere teşekkür etmiştir. Yine sergiye katılım sağlayan çevre vilayetlere, özellikle Kastamonu ve Trabzon vilayetine şükranlarını ifade etmiştir. Ayrıca mesai arkadaşları ve eşrafin gösterdiği emekten memnuniyet duyduğunu belirtmiştir. Padişaha dua etmiş ve "Padişahım çok yaşa" lafzı ile nutkunu sonlandırmıştır. ${ }^{75} \mathrm{Bu}$ esnada meydanda bulunan kişiler de hep bir ağızdan aynı lafzı üç defa tekrar etmiştir. ${ }^{76}$

74 Sabah Gazetesi, No: 4975, 1321 C. 9/1 Eylül 1903, s. 4; Sabah Gazetesi, No: 4977, 1321 C. 11/3 Eylül 1903, s. 1; Tercümanı Hakikat Gazetesi, No: 2846-8046, 1321 C. 24/16 Eylül 1903, s. 2; İkdam Gazetesi, No: 3318, 1321 C. 24/16 Eylül 1903, s. 2; Ek-1, Sivas Vilayet Salnamesi, Def'a 17, 1325.

75 Sabah Gazetesi, No: 4990, 1321 C. 24/16 Eylül 1903, s. 2-3; İkdam Gazetesi, No: 3318, 1321 C. 24/16 Eylül 1903, s. 2-3.

76 Tercümanı Hakikat Gazetesi, No: 2846-8046, 1321 C. 24/16 Eylül 1903, s. 3. 
Mehmet Reşit Akif Bey'in nutkundan sonra Sivas Maarif Müdürü Tahir Bey tarafından ayrı bir nutuk okunmuştur. Tahir Bey nutkunda serginin faydalarından bahsetmiş ve taşradan gelen misafirleri hoş cümleler ile takdir etmiştir. ${ }^{77} \mathrm{Bu}$ iki nutka müteakip Sivas Müftüsü Fehim Efendi tarafından bir dua okunmuştur. Sonrasında görevli bulunan bir memur tarafindan Vali Reşit Akif Bey'e serginin gerçekleştiği binada bulunan dairlerin anahtarları teslim edilmiştir. Vali ve beraberindekiler birer birer sergi şubelerinin resmi açılışını ahalinin alkışları ve bando eşliğinde gerçekleştirmiştir. Sonrasında ise ziyaretçiler ile birlikte heyet, sergi binasını gezmeye başlamıştır. Bu esnada dokuma şubesinin açı1ışında Sivas halıcılarından Mircan Efendi ${ }^{78}$ tarafından ayrıca bir nutuk daha okunmuştur. Vali Reşit Akif Bey, sergi şubelerinin açılışı gerçekleştirdikten sonra sergi solanlarını gezerken bazı eşyaları satın almıştır. Sivaslı bir üstadın sanatkârane yaptı̆̆ 1 bir bastonu maden şubesinden, Sivas'ta marangozluk ürünlerinde ilerleme sağlayacak ölçüde ve güzel bir surette imal edilmiş zarif bir çekmeceyi marangozluk şubesinden, Kastamonu'da imal edilen mükemmel resimli bir halı ile bazı eşyayı da dokuma şubesinden ücreti mukabilinde satın almıştır. Bu esnada Kastamonu Vilayeti'nden gelen eşyaları birer birer dikkatle incelemiş, sonrasında bu eşyaların özel görevlisi olarak sergide bulunan Hafiz Hüsnü Efendi’yi takdir etmiştir. Ayrıca sergi açılışı ve sergi salonlarını gezen diğer kişiler de bazı eşyaları satın almıştır. Bütün daireler gezildikten sonra yine kabul salonuna dönülmüş ve burada hazır bulunan kişilere tatlı ikram edilmiştir. Kabul salonunda bir müddet istirahattan sonra Vali ve maiyetindekiler yeni tamamlanan telgraf hattını görmek ve açılışını gerçekleştirmek amacıyla telgraf dairesine geçmiştir. Saat yaklaşık dokuz buçukta Vali ve maiyetindekiler sergi binasından ayrılmıştır. ${ }^{79}$

\section{Sivas Serginin İçeriği}

Ziyaretçiler sergi binasına ilk girdiğinde kabul salonuna ulaşırlar. Kabul salonuna girildiğinde burada teşhir edilen ürünlerin tamamının Osmanlı Devleti'nde imal edilen ürünler olduğu görülmektedir. Söz konusu salonun ortasında Sivas marangozlarının imal ettiği oval şekilli ve oymalı cevizden bir masa, masanın üzerinde Ürgüp’te imal edilen gayet latif bir yazı takımı, tam kapının karşısında yine oymalı cevizden bir koltuk sandalye ve etrafinda yine oymalı cevizden bir

77 İkdam Gazetesi, No: 3316, 1321 C. 22/14 Eylül 1903, s. 2.

78 Mircan Efendi, Sivas Halı Fabrikasının kurucudur. 1901 tarihinde Konya'da düzenlenen Ha11-Kilim Sergisi'ne katılmış ve teşhir ettiği ürün burada birincilik derecesi kazanmıştır. Sivas Sergisi'nde ise aynı zamanda dokuma şubesi heyetinde görev almıştır. Sivas Vilayet Salnamesi, Def'a 16, 1321, s. 229, 232; Hüseyin Muşmal, agm., s. 246.

79 Tercümanı Hakikat Gazetesi, No: 2846-8046, 1321 C. 24/16 Eylül 1903, s. 3. 
koltuk bulunmaktadır. Söz konusu koltuğun döşemeleri ise zarafeti ile bilinen Gürün şallarından yapılmıştır. Kabul salonunun tabanında askeri kışladan getirilen tek parça bir kilim ve pencerelerinde ise zarif cicim türü perdeler bulunmaktadır. Salonun tavanı ve duvarları pembedir. Zemini ise mavi renklidir ve mavi rengin üzerinde de boya ve nakışlı süslemeler bulunmaktadır. Bu durum ise kabul salonunun tefrişatını ve güzelliğini arttırmıştır. Kabul salonunda yer alan levhalardan üç tanesi ziyaretçilerin takdirini kazanmıştır. Bunlardan birisicisi, kenarları resimli, parlak ve saf ipek işlemeli kabartmadır. Sivas İnas Rüştiye Mektebi Birinci Muallime'si Süheyla Hanım'ın mahsulü ve mahareti olan bu eser ziyaretçilerin takdirini kazanmıştır. Diğeri yine bir kenarı resimli olmak üzere boncukla işlenmiş olan bir levhadır. Sivas Hapishanesi'nde hazırlanmış olan bu levhanın sanatkârane bir üründen ziyade uzaktan bak1lınca adeta boyalı bir resimden fark edilemeyecek derecede yapıldığı anlaşılmıştır. Ayrıca renk, şekil ve ahenk uyumu bakımından takdir kazanmış bir eserdir. ${ }^{80}$ Üçüncüsü ise Askeri Rüştiye talebesinden bir efendinin yapmış olduğu yağlı boya resmidir. Bunların haricinde başka levhalar da kabul salonunda teşhir edilmiştir. ${ }^{81}$

Kabul salonundan binanın merkezindeki büyük salona geçilmektedir. Büyük salon herhangi bir teşhir şubesine ait olmamasına rağmen temaşası ve güzelliği ile meşhur olmuştur. Burası aynı zamanda ilk teşhir dairesi olarak hazırlanan dokuma şubesinin girişindeki salondur. İlk önce geniş bir kapı aralığına tesadüf edilmektedir. Sağda ve solda diğer dairelere açılan ufak birer kapı ve önünde dahi asıl salona açılan iki kanatı büyük bir kapı yer almaktadır. Büyük salon girişinin zemini baştanbaşa çeşitli halılarla kaplanmıştır. Bu halılar hakikaten şark usulüne layık olan dokumalardır. Bunların altında ise dayanıklı, renkli, nakışlı ve renk uyumu bulunan güzel bir taban halısı bulunmaktadır. Niğde Mutasarrıflı̆̆ı'ndan gönderilen eşyalar arasında yer alan söz konusu taban halısına alıcılar tarafından yüz lira fiyat verilmiştir. Fakat Niğde Mutasarrıflı̆̆ı'nın temsilcisi söz konusu halının satı1ılık olmadığını bildirmiştir. Bu salonun ortasında bir masanın üzerinde teşhir edilen ve Niğde mamulâtından bir halı seccadesi takdir kazanmıştır. $\mathrm{Bu}$ seccadenin ortasına gayet geniş ve düzgün bir tuğrayı hümayun işlenmiştir. Tuğranın etrafına ise İstanbul dâhil bütün Osmanlı vilayetlerin isimleri latif bir ahenk ile yazılmıştır. Gerçekte sanat bakımından değerlendirildiğinde resimli ve yazılı halılara pek fazla ehemmiyet verilemese de bu nakışlı seccade takdiri hak etmiştir. Büyük salon kapısının üstünde sırma ile işlenmiş tuğrayı hümayun içeren bir levha yer almaktadır. Ayrıca bu kapı üzerine asılan ve cicimden imal edilen perde dikkat çekmektedir. Kangal Kazası mamulâtından olan bu perdelik, yedi metre

80 Tercümanı Hakikat Gazetesi, No: 2857-8057, 1321 B. 5/27 Eylül 1903, s. 3.

81 İkdam Gazetesi, No: 3316, 1321 C. 22/14 Eylül 1903, s. 2. 
uzunluğunda ve üç buçuk metre genişliğindedir. İğne ile işlemek suretiyle yapılmıştır. Ayrıca söz konusu perdenin üretiminde has yerli boya kullanılmıştır. ${ }^{82}$

Büyük Salon'dan ilk teşhir dairesi olarak hazırlanan dokuma şubesine ${ }^{83}$ geçilmektedir. Söz konusu şubede Darendeli Ömer oğlu Ahmet Efendi, teşhir edilen ürünler hakkında ziyaretçilere malumat vermiştir. Burada sergilenen teşhir ürünleri arasında özellikle bazı halılar ziyaretçilerin takdirini kazanmıştır. Bunlar; Kastamonu Sanayi Mektebi mamulünden bir hal1, Paris'teki Opera Caddesi'nin resmedildiği diğer bir halı ve Sivas halı fabrikası ürününden olan başka bir süslü halıdır. Söz konusu üç halı renk uyumu açısından dikkat çekmiştir. Bunların yanı sıra Gürün'den gönderilmiş ve tamamen ipekten yapılmış sanatkârane bir halı daha bulunmaktadır. Ayrıca İran tarzı, yerli boyalardan imal edilmiş ve İskender'in resmedildiği halı da ilgi çeken halılar arasında yer almıştır. Halıların yanı sıra Gürün'ün şal ve kumaşları ile Amasya ve Tokat'ın ipek mamulleri de mükemmeliyetiyle dikkat çekmiştir. Bununla birlikte Sivas İnas Mektebi Muallimesi Süheyla Hanım'ın yetiştirdiği dördüncü ve beşinci sınıftan bazı öğrenciler de ürünlerini dokuma şubesinde teşhir etmiştir. Bunlar ise ipekten imal etmiş oldukları Avrupa haritası ve sanatkârane yapmış oldukları seccadelerdir. Söz konusu şubede camekânların içinde teşhir edilen tamamen yerli mamullerden bulunan çeşit çeşit kuşak, entari ve kumaşlar da yer almıştır.

Dokuma şubesinden maden şubesine geçişte arada iki küçük oda yer almaktadır. Söz konusu iki odada ise Sivaslı ve Sanayi-i Nefise Mektebi mezunu olan Neşan Avak Efendi tarafından resmedilmiş maharetli tablolar teşhir edilmiştir. Ayrıca Kayseri ve Kırşehir halıları da burada sergilenmiştir.

Maden şubesinde ${ }^{84}$ teşhir edilen eşyalar ziyaretçilerin ilgisini çekmiştir. Komiser Hamdi Bey ve Sivas mühendislerinden Abdüssamet Sami Efendi, söz konusu şubede teşhir edilen ürünlerin tanıtımı yapmıştır. Burada eski usul kılıç, hançer ve zırhlar duvarları süslemiştir. Yine camekânlarda birçok latif eşya sergilenmiştir. Özellikle Senek Usta tarafından taştan yontularak yapılmış fener sanat bakımından dikkat çekmiştir. Ayrıca Karahisar-1 Şarki’ye Bağlı Hamidiye Kazası

82 Tercümanı Hakikat Gazetesi, No: 2857-8057, 1321 B. 5/27 Eylül 1903, s. 3.

83 Dokuma Şubesi Heyeti: Reis Adliye Müfettişi Hulusi Bey'dir. Azalar; Mehmet Fehim Efendi, Eşraftan Nuri Bey, Eşraftan Beyan Efendi, Tüccardan Darendeli Ömer Efendi, Tüccardan Batumlu Ahmet Efendi, Tüccardan Keşişyan Nişan Efendi, Tüccardan Şahinyan Avadis Efendi, Tüccardan Bostancı oğlu Yosfaki Efendi, Tüccardan Alber Alyoti Halı Fabrikası Direktörü Enizzeler Efendi, Tüccardan Halıcı Mircan Efendi ve Tüccardan Mıgırdıç Efendi'dir. Sivas Vilayet Salnamesi, Def'a 16, 1321, s. 233.

84 Maden Şubesi Heyeti: Reis Adliye Müfettişi Mihail Latif Efendi'dir. Aza ise Ser-mühendis Mösyö Şarteyn'dir. Sivas Vilayet Salnamesi, Def'a 16, 1321, s. 233. 
ahalisinden Ali Çavuşzade Sami Efendi tarafından yapılmış bisiklet burada yer almıştır. Söz konusu kişi ayrıca içinde fotoğraf ve arma bulunan bir saat de teşhir etmiştir. Yine bu şubede Evkafi Hümayun Nezareti Mektubi Kalemi'nden Sivaslı Fethi Beyzade Abdülkadir Zekeriya Bey Efendi'nin Hint usulü bir çekmecesi teşhir edilmiştir. Söz konusu eserin özellikle işlemesi mükemmeldir. Bunların yanı sıra Askeri mülazımlarından Kemal Efendi'nin sanatkârane gemisi ve Mülkiye doktorlarından Sivaslı Mahmut Nedim Efendi'nin iskelet resmi de burada teşhir edilen diğer ürünler arasında yer almıştır.

Marangozluk şubesi ile hayvancılık ve dericilik şubeleri arasında tablo, levha ve halılarla süslenmiş bir gezinti alanı vardır. Burada mavi zemin üzerine beyaz ipekle işlenmiş gayet güzel bir tuğra yer almıştır. Ayrıca Sivas ressamlarından Şimşiryan Osekhan Efendi'nin birçok tablosu da bu gezinti alanında teşhir edilmiş ve ziyaretçiler tarafından beğenilmiştir.

Marangozluk şubesinde ${ }^{85}$ teşhir edilen ürünler özellikle sanat bakımından dikkat çekmiştir. Bu şubedeki eşyalar hakkında ziyaretçilere tafsilatlı bilgi, Sivas Mektubi Kalemi Kütüphanesi'nden Rüştü Bey ve tüccardan Hafiz Sabri Efendi tarafindan verilmiştir. Söz konusu şubede, Hacı Kirkor'un kapaklı, sürgülü, yirmi dört gözlü ve cevizden imal ettiği çekmece ile Zile'den Halit Efendi'nin imal etiği diğer bir çekmece dikkat çekmiştir. Yine Merzifonlu Artin Konakçiyan'ın pek mükemmel bir tarzdaki kanunu ile Sivaslı Şahinyan Pervandek'in Avrupa kemanlarından katiyen farksız bir surette imal ettiği kemanı da yer almıştır. Ayrıca Sivaslı Zigal oğlu Kirkor'un imal ettiği ve hepsinde ayrı bir sanat değeri bulunan tabaka ile tütünlükleri de teşhir edilmiştir. Bunların yanı sıra yerli mamulâttan olup gerek Sivas Vilayeti’nden gerek ise çevre vilayetlerden gönderilmiş ve Avrupa tarzı eşyalardan daha üstün bulunan birçok karyola, sandalye, masa ve baston sergilenmiştir. Söz konusu şubede Vali Reşit Akif Bey'in antika bir çekmecesi ile Seyit Ahmet Paşazade Abbas Hulusi Bey'in fildişi taşlarla süslü ve nakışlı bir çekmesi dahi teşhir edilmiştir.

Marangozluk şubesinden hayvancılık ve dericilik şubesine ${ }^{86}$ geçilmektedir. Burada teşhir olunan eşyalar arasında özellikle Maraş ürünleri dikkat çekmiştir.

85 Marangozluk Şubesi Heyeti: Reis Erkan-1 Harbiye Kaymakamı Mustafa Bey’dir. Azalar; Nüfus Nazırı İbrahim Bey, Kolağası Cemal Bey, Meclis İdare Azası Abdah Bey, Meclis İdare Azası Ali Efendi, Balyozyan Hamparsum Efendi, Marangoz Ohennes Usta, Marangoz Bakkal oğlu Kirkor Usta ve Beledi Kalfası Ohennes Usta'dır. Sivas Vilayet Salnamesi, Def'a 16, 1321, s. 232.

86 Hayvancılık ve Dericilik Şubesi Heyeti: Reis Hamidiye Alay Kumandanı Bedri Bey'dir. Azalar; Defterdarı Hakani Memuru Refet Bey, Eşraftan Emir Bey, Meclis İdare Azasından Kabriyel Efendi, Hamidiye Yüzbaşısı İsmail Efendi, Eczacı Mehmet Efendi, Baytar Müfettişi Vasilaki Efendi, Kasım Ağazade Şükrü Efendi, Reşit Ağazade Ali Efendi ve Kunduracı Dikran Usta'dir. Sivas Vilayet Salnamesi, Def'a 16, Sivas, 1321, s. 232. 
Söz konusu şubedeki ürünler Avrupa mamullerinden daha sağlam ve ucuzdur. Burada sahtiyan, güderi, kundura, potin, çamurluk, at koşum takımları ve muhtelif ürünler teşhir edilmiştir. Özellikle Aziziyeli Hasan Bey'in Çerkez at koşum takımı ve Amasya'dan gönderilmiş birçok Türk eyeri takdir kazanmıştır. Ayrıca söz konusu şubede iki baş ve altı ayaklı doğmuş ve bir müddet yaşamış manda yavrusunun vücudu da sergilenmiştir.

Marangozluk şubesinden Ziraat şubesine geçilirken arada bulunan gezinti alanında ise singer makinesi teşhir edilmiştir. Sivas Sergisi'nde yer alan son teşhir salonu ise Ziraat şubesine ${ }^{87}$ ayrılmıştır. Söz konusu şubede Sivas Numune Çiftliği Müdürü Hamdi Bey tarafından icat edilmiş yeni tür arı kovanı ve tarladaki ekinlere zarar veren köstebekler için yeni buluş bir tuzak teşhir edilmiştir. Yine son sistem yayıklar ve muhtelif makineler de istifadeye sunulmuştur. Ayrıca Orman ve Maden Nezareti'nden gönderilen yeni usul ziraat makineleri komisyon tarafından memnuniyetle karşılanmış ve burada teşhir edilmiştir. Söz konusu makineler Sivas numune çiftliği müdür muavini tarafından denenmiş ve olumlu sonuç vermiştir. ${ }^{88}$

Sivas Sergisi'nde teşhir edilen eşya ve ürünlerin ekonomik değeri bulunmaktadır. Sadece dokuma şubesinin bir odasındaki ürünlerin değeri dört-beş bin liraya ulaşmıştır. ${ }^{89}$ Sivas Sergisi'ne Kastamonu, Trabzon, Canik, Niğde, Kayseri, Kırşehir, Malatya, Erzincan ve Maraş gibi birçok şehirden katılım gerçekleşmiştir. ${ }^{90}$ Bununla birlikte Kastamonu ve Trabzon vilayetlerinden gönderilen eşya ile ürünlerin miktar ve çeşitliliği diğer vilayetlere nispetle daha fazladır. Ziyaretçilerin satın aldığ bilet bir kuruştur ve sadece tek giriş için geçerlidir. Düzenlenen bu sergiyi her gün yüzlerce kişi ziyaret etmiştir. Hatta sergide önemli miktarda satış da gerçekleşmiştir. Bunların yanı sıra sergi haftada iki gün kadınlara tahsis edilmiştir. ${ }^{91}$

87 Ziraat Heyeti: Reis Kaymakam Fahri Efendi'dir. Azalar; Ziraat Müfettişi Hamdi Bey, Banka Memuru Ali Rıza Efendi, Belediye Reisi Tevfik Efendi, Çiftlik Müdür Muavini Ali Osman Efendi, Tüccardan Kemahlı oğlu Hüseyin Efendi, Bakkal Seyit Ahmet Ağa, Çıkrıkçı oğlu Kabriyel Efendi ve Maarif Muhasebecisi Mehmet Reşit Efendi’dir. Sivas Vilayet Salnamesi, Def'a 16, 1321, s. 232.

88 İkdam Gazetesi, No: 3316, 1321 C. 22/14 Eylül 1903, s. 2.

89 Sivas Vilayet Salnamesi, Def'a 17, 1325, s. 239.

90 Sabah Gazetesi, No: 4975, 1321 C. 9/1 Eylül 1903, s. 4.

91 İkdam Gazetesi, No: 3316, 1321 C. 22/14 Eylül 1903, s. 2. 


\section{Sivas Serginin Hatırası İpekli Mendil ve Kartpostallar}

Sivas Sergisi'nin güzel bir hatırası olması amacıyla ortasında Sivas Vilayeti'nin haritası ve haritanın üst tarafinda Sivas manzarasından bir resim bulunan üç bin ipekli mendil, Orman, Maden ve Ziraat Nezareti vasıtasıyla fabrikalara sipariş verilmiştir. ${ }^{92}$ Gayet latif bir surette imal edilen bu mendillerin üzerinde Sivas Vilayeti'nin haritası pek mahirane bir tarzda resmedilmiş ve yazıları da pek nefis bir sülüs ile basılmıştır. ${ }^{93}$ Mendilin üzerinde bir Osmanlı arması ve armanın altında "saye-i umrân pîrâye-i Cenâb-ı Padişâhîde atûfetlü Reşit Akif Bey Efendi hazretlerinin zamân-ı vilâyetlerinde birinci defa olarak Sivas'ta küşâd olunan ve yevm-i mesûd-ı cülus-ı hümâyûn-ı mülükâneye müsâdefetle mübahî olan ziraat ve sınaat sergisinin hatırasıdır" ibaresi yazılmıştır. ${ }^{94}$ Bazı mendillerin üst kısmında sergi binasının resmi de yer almıştır. Mendiller sanat yönünden değerli bulunmuştur. Söz konusu mendiller satışa sunulduğu gibi devlet kurumları ile İstanbul'da bulunan gazete matbaalarına da hatıra ve tanıtım amaciyla gönderilmiştir. Bu davranış ise memnuniyetle karşılanmıştır. ${ }^{95}$ Fakat Sivas'ta düzenlenen bu serginin birinci hedefi belirttiğimiz üzere burada teşhir edilen ürünlerin Osmanlı mamul ve mahsulü olmasıdır. Ayrıca yerli ürünlerin yaygınlık kazanması da hedeflenmiştir. Bununla birlikte serginin hatırası olması amacıyla hazırlanan söz konusu mendiller Viyana'ya sipariş verilmiş ve Viyana'dan getirilmiştir. ${ }^{96} \mathrm{Bu}$ ise serginin amaç ve hedefi ile çelişmektedir. Mendillerin yanı sıra Sivas manzarası, Sivas'taki muhtelif bina ile Sivas'a ait eski eser resimlerinin yer aldığ 1 on bin adet kartpostal da Dersaadet matbaalarına sipariş verilmiştir. ${ }^{97}$ Söz konusu ipekli mendil ve Sivas manzaralı kartpostallar alıcılar tarafindan fazlasıyla rağbet görmüş ve ilerleyen süreçte de kullanımda yerini almıştır. ${ }^{98}$

\section{Sivas Sergisi Hakkında Düşünceler}

Sivas Sergisi hakkında düşünceler vilayet salnamesi ve basında yer almıştır. Sergi izlenimleri, serginin olumlu yönleri ve sergi sonucunda ortaya çıkan problemler açıça ifade edilmiş ve çözüm yolları ortaya koyulmuştur. Sivas özelinde belirtilen düşünceler Osmanlı ekonomisinin olumlu-olumsuz yönlerine 1şık tut-

92 Sivas Vilayet Salnamesi, Def'a 16, 1321, s. 228.

93 İkdam Gazetesi, No: 3332, 1321 R. 8/30 Eylül 1903, s. 3.

94 Bknz; Ek-2. Fotoğraf paylaşımı için Uğur Yeğin Bey’e teşekkür ederim.

95 Tercümanı Hakikat Gazetesi, No: 2861-8061, 1321 B. 9/1 Ekim 1903, s. 2.

96 BOA. ŞD 595/34 1321 Z. 4/21 Şubat 1904; Tercümanı Hakikat Gazetesi, No: 2818-8018, 1321 Ca. 25/19 Ağustos 1903, s. 1.

97 Sivas Vilayet Salnamesi, Def'a 16, 1321, s. 228.

98 Sivas Vilayet Salnamesi, Def'a 17, 1325, s. 240. 
muş ve kendisinden sonra düzenlenecek sergilere de örnek olmuştur. Buna göre; Sivas Sergisi, Osmanlı Devleti'nin sanayi durumu dikkate alındığından dokuma, hayvancılık ve dericilik, maden, marangozluk ile ziraat şubelerine ayrılmıştır. Serginin hazırlık aşaması ve sergi sürecinde yetkililer tarafindan iyi niyet gösterilmiş ve ciddi bir emek harcanmıştır. Gerçekte serginin düzenlenmesinde yer alan görevlilerin daha öncesinde sergicilik konusunda bir tecrübesi bulunmamaktadır. Ayrıca Sivas ahalisi de serginin faydalarını tam olarak kavrayamamıştır. Buna rağmen birkaç aylık verimli bir çalışma ile birlikte güzel bir netice alınmıştır. ${ }^{99}$ Hatta bu dönemde sergi için bütün eşraf, memur ve tüccar aralarında olumlu bir rekabet ortamı oluşturmuştur. Böylelikle Anadolu'nun ortasında güzel ve yeni bir medeni gelişme yaşanmıştır. ${ }^{100}$

Sivas Vilayeti'nin her bölgesinden gelen mamulât ve mahsulât numuneleri burada düzenli bir şekilde teşhir edilmiştir. Ayrıca çevre vilayetlerden gönderilen güzide eşyalar da sergide yerini almıştır. Söz konusu şehirlerden birçok mamulât ve mahsulât ile beraber tüccar, sanatkâr ve alanında uzman memurlar da sergide hazır bulunmuştur. Sivas Vilayeti ile çevre vilayetlerden gelen mamul ve mahsullerin bir arada sergilenmesi, ürünlerin incelenmesi ve mukayese edilmesini sağlamıştır. Ayrıca sanatkârların kendisini ıslah etmesini sağladığı gibi tüccarlara da faydalı fikirler sunmuştur. Bu sergide sağlanan başarı, ileride ikinci bir serginin açılması düşüncesini kuvvetlendirmiştir. ${ }^{101}$ Bununla birlikte 1914 tarihinde yine Sivas'ta aynı amaçla ve benzer bir serginin açılması gündeme gelmiştir. Bu sergi için düzenlenen nizamname 1903 tarihindeki nizamnameyi temel alarak hazırlanmıştır. ${ }^{102}$

Sivas Vilayeti teşhir edilecek birçok mamulât ve mahsulâta sahiptir. Vilayetin çoğu bölgesinde teşhire uygun ziraat mahsulü yetiştiği gibi vilayetin sanayisi dahi değerlidir. Merkez sancağın çeşit çeşit halı ve kilimleri, marangoz ve demirci mamulâtı, zarif çubukları, dökme lamba ve şamdanları, Gürün'ün güzel kumaşları, Amasya'nın ipek dokuması, Aziziye'nin Çerkez kumaşları, Merzifon'un havlu ve hamam takımları sergilenmeye ve rağbet görmeye layıktır. ${ }^{103}$ Bununla birlikte sergilenen ürünlerin kıymet ve değeri beklenilenin fevkalade üstünde olmuştur. Bu durum sadece Sivas Vilayeti'nden değil çevre vilayetlerden gelen kişiler tarafindan da kabul edilmiştir. Sivas'ta sınaat ve ziraat alanında böyle par-

99 Sivas Vilayet Salnamesi, Def'a 17, 1325, s. 240.

100 Sabah Gazetesi, No: 4975, 1321 C. 9/1 Eylül 1903, s. 4.

101 Sivas Vilayet Salnamesi, Def'a 17, 1325, s. 240.

102 BOA. DH. İD 108/26 1332 Ca. 29/25 Nisan 1914.

103 Sivas Vilayet Salnamesi, Def'a 16, 1321, s. 230-231; İkdam Gazetesi, No: 3198, 1321 S. 10/8 Mayıs 1903, s. 3. 
lak ve mühim bir serginin düzenlenebileceği başlangıçta ümit edilememiştir. Bu durum ayrıca bir iftihar duygusu oluşturmuştur. Bilhassa Amerika Konsolosu Mr. Jewett ve Sivas'ta bulanan diğer konsoloslar bu durumu onaylamıştır. Söz konusu konsoloslar sadece Sivas'ta değil birçok Osmanlı Vilayeti'nde dahi bu mükemmeliyette ve çeşitlilikte bir serginin gerçekleşebileceğini hiçbir vakit akıllarına getiremediklerini bildirmişlerdir. Ayrıca bu sergiden memnun kaldıklarını ve bu sergiyle iftihar ettiklerini beyan etmişlerdir. Bunun yanı sıra sergi hususunda Vali Reşit Akif Bey'i samimiyet ve ciddiyetle takdir etmeğe mecbur olduklarını bildirmişlerdir. ${ }^{104}$

Sivas Sergisi'nde teşhir edilen ürünler Osmanlı mamul ve mahsulü ürünlerdir. Özellikle bu amacın gerçekleşmesine dikkat edilmiştir. Bu bağlamda değerlendirildiğinde sergide teşhir edilen dokuma ürünleri iki bölüme ayrılmaktadır. Birinci bölüm; ham maddesinden mamul haline gelinceye kadar her devriyesi ve sanayisi Osmanlı Devleti'ne ait olan dokumalardan oluşmaktadır. Bu ürünlerde başka bir devletin en ufak bir katkısı bulunmamaktadır. Gerçek manada Osman11 mamulleri bu bölüm kapsamında değerlendirilir. Halı, kilim, ipekli dokuma ile Çerkez kumaşları bu bölüme dâhildir. Bunların yünleri ve ipekleri Osmanlı Devleti'nde imal edilir, renklendirilir, boyanır ve işlenerek dokunur. Söz konusu ürünlerin hammaddesi, gayreti, mesaisi ve sanatı tamamen Osmanlı Devleti'ne aittir. Gerçekte ehemmiyet verilen ürünler bu bölümde yer almaktadır. İkinci bölüm dokuma ürünleri ise iplikleri hazır olarak yabancı devletlerden getirildikten sonra Sivas'ta dokuması gerçekleşenlerdir. Hamam takımı, havlu ve tire dokumalarının ipliği boyanmış olduğu halde Manchester'dan getirilmektedir. Ayrıca Gürün kumaşları da bu bölümde yer almaktadır. Bunlar kısmen Osmanlı mamulü kabul edilse dahi ekonomik ehemmiyeti bakımından birinci bölümdeki ürünlere göre geride kalmaktadır. Söz konusu mamullerin sadece imalatı Sivas'ta gerçekleştiğinden kazancı da az olmaktadır. Çünkü yabancı bir devletten iplik ile kumaş ithal etmek arasında kazanç bakımından pek fazla bir fark bulunmamaktadır. Bunun içindir ki Gürün kumaşlarının maliyeti Avrupa kumaşlarının maliyetine göre yüksek bir fiyata mal olmaktadır. Bu ise tertibat ve mesaiye rağmen gelişmeyi ve Sivas mamullerinin yaygınlaşmasını engellemektedir. Yine sergide teşhir edilen Erzincan mamulü yüz havluları zarafet bakımından herkesin dikkatini çekmiştir. Buna rağmen benzer Avrupa mamulü havlulara göre birkaç kuruş daha pahalı olduğu için rağbet görmemiştir. Söz konusu mamullerin az-çok satılması ise yerel zevki taşımasından kaynaklanmaktadır. Fakat sadece yerli ürün olması tüketicilerin bu ürünü tercih edeceği anlamına gelmemektedir. Yerli mamul ile Avrupa ma- 
mulü arasında fiyat bakımından bir eşitlik olması durumunda tüketiciler tercihini yerli ürün için kullanmaktadır. Bununla birlikte tüketici, tercih esnasında haklı olarak fiyatı dikkate almaktadır. Bu sebeple Avrupa mamulü ile rekabet etmek ve yerli ürünü yaygınlaştırmak için Avrupa mamullerinden daha ucuza hiç olmazsa aynı fiyata satışı gerçekleştirmek gerekmektedir. Ancak böylelikle yerli sanayi gelişme gösterir ve yerli tüccar kazanır. Gerçekte Osmanlı Devleti'nin şartları uygundur. Memleketin her yerinde her türlü hammadde ucuz ve boldur. Zirai mahsulâtın her türlüsü memlekette yetişmektedir. Burada yapılması gereken uygun sanayi makinelerini memlekete getirmek, teknik gelişmelerden istifade etmek ve iplik fabrikaları kurmaktır. Dokuma sektöründe istenen düzeye ulaşmak için belirtilen şartları sağlamak gerekmektedir. ${ }^{105}$ Anlaşıldı̆̆ 1 üzere düzenlenen sergi sonucunda ortaya çıkan sonuç, özelde Sivas Vilayeti genelde ise Osmanlı Devleti'ni ilgilendirmektedir.

\section{Sonuç}

Sivas Sergisi dönemin sosyal yaşamına, ihtiyacına ve ekonomisine yönelik hedefleri bulunan bir organizasyondur. Ekonomik bağlamda yerli üretimin ön plana çıkarılması ve yaygınlaştırılması hedeflenmiştir. Sergide teşhir ürünlerinin Osmanlı mamul ve mahsulü olması şart koşulmuştur. Hatta dokuma, nakış ve üretim mamullerinde Avrupa tarzından ziyade şark usulüne uygun olanlar tercih edilmiş ve desteklenmiştir. Bununla birlikte Sivas ürünlerine ağırlık verilmiş ve bu ürünlerinin teşhiri kolaylaştırılmıştır. Böylelikle özelde Sivas genelde ise Osmanlı ekonomisine kazanım sağlanması hedeflenmiştir. Sivas Sergisi'nin hazırlık sürecinde Osmanlı yerel sergiciliğinde daha öncesinde kazanılan tecrübeden istifade edilmiştir. Ayrıca söz konusu süreçte sergi komisyonu kurulmuş, teşhir şubelerinde görev alacak heyetler belirlenmiş ve görev dağılımı yapılmıştır. Serginin düzenlenmesi ve işleyiş̧i konusunda yirmi maddelik bir nizamname hazırlanmıştır. Sergi ile ilgili arşiv belgeleri ve basın haberleri incelendiğinde, Sivas Sergisi'nin ciddi bir çabanın ürünü olduğu anlaşılmaktadır.

Sivas Sergisi 1 Eylül 1903 tarihinde yani II. Abdülhamit'in tahta çıkış yıl dönümünde Hamidiye Sanayi Mektebi'nde açılmıştır. Sivas ve çevresinde günlük hayatın nerdeyse her alanında kullanılan eşya ve ürünler bir arada teşhir edilmiştir. Bu ürünlerin maddi değerinden ziyade hepsinin Osmanlı mamul ve mahsulü olması, amacına uygun bir surette gerçekleştiğini göstermiştir. Ayrıca teşhirde çokluktan ziyade çeşitlilik hedeflenmiş ve bu bağlamda Sivas Sergisi başarılı bulunmuştur. Bu anlamda Sivas'ta ilk defa gerçekleştirilen sergiye Kastamonu, 
Trabzon, Canik, Niğde, Kayseri, Kırşehir, Malatya, Erzincan ve Maraş gibi birçok şehirden katılım sağlanmıştır. Bununla birlikte teşhir ürünlerinin temsil ettiği coğrafi bölge değerlendirildiğinde bu serginin bölgesel bir özellik taşıdığı görülmektedir. Sergide ürün teşhir edenler incelendiğinde ise nerdeyse her çeşit meslek gurubundan katılımcı olduğu anlaşılmaktadır. Ayrıca öğrenci ve mahkûmların ürünleri de sergide teşhir edilmiştir. Bununla birlikte kadınların hem katılımcı hem de ziyaretçi olarak organizasyonun içinde yer aldıkları görülmektedir.

Sivas Sergisi ürünlerin ihracat ve ithalat durumunu, hammadde ve ürün haline getirme sürecini, değerinin belirlenme aşamasını ve bölgenin ekonomik yapısını ortaya koymuştur. Sergi sonucunda Sivas ve çevresinde hammaddenin bol olduğu, tarımsal ve hayvansal ürün çeşitliğinin varlığı, ürün kalitesinin yüksek olduğu ve el sanatı ürünlerinin gelişmişliği görülmektedir. Ayrıca sanayi mamullerinin varlığının da dikkate değer boyutta olduğu anlaşılmaktadır. Kısacası; bölgenin ekonomik performansını göstermiş, kaliteli üretim kapasitesini açıça ortaya koymuş ve zenginliklerini temsil etmiştir. Buna rağmen Avrupa ürünlerinin sanayileşme sayesinde daha ucuza mal edildiği ve bu sebeple yerli ürünlerin rağbet görme konusunda geride kaldığı gerçeği bir defa daha ortaya çıkmıştır. Bununla beraber özellikle imalat sektöründe yaşanan problem ve eksikliklere dikkat çekilmesini sağlamıştır. Bu sebeple sergi sonucunda özellikle makineleşme konusunda k1sa, orta ve uzun vadeli tedbirlere ihtiyaç hissedilmiştir. Bu problemin çözümü ve yerli ürünlerin yaygınlık kazanması konusunda tedbirler ve gerçekçi öneriler sunulmuştur. Bu kapsamda; ürünlerin hammaddeden mamul haline gelinceye kadar her devriyesi ve sanayi sürecinin Osmanlı Devleti'ne ait olması gerekliliği bildirilmiştir. Bu amaçla uygun sanayi makinelerinin memlekete getirilmesi, teknik gelişmelerden istifade edilmesi ve iplik fabrikalarının kurulması önerilmiştir. Sivas Sergisi Osmanlı Devleti'nin içinde bulunduğu olumsuz süreçten etkilenmesine rağmen sanayi ve ziraata katkı sağlamış, Sivas ticaretine canlılık getirmiş ve işlevini başarıyla tamamlamıştır. 


\section{Kaynakça}

\section{A. Arşiv Kaynakları (BOA)}

Bâb-1 Âlî Evrâk Odası: BEO 2046/153392 1321 M. 18/16 Nisan 1903; BEO 2064/154788 1321 S. 12/10 Mayıs 1903; BEO 2081/156025 1321 Ra. 4/31 May1s 1903; BOA. BEO 2087/156507 1321 Ra. 13/9 Haziran 1903; BEO 2106/157904 1321 R. 8/4 Temmuz 1903; BEO 2131/159805 1321 Ca. 10/4 Ağustos 1903.

Bâb-1 Âlî Evrâk Odası, Şûra-yı Devlet: ŞD 595/34 1321 Z. 4/21 Şubat 1904.

Dâhiliye Nezâreti, İrade: DH. İD 108/26 1332 Ca. 29/25 Nisan 1914.

İrade, Dâhiliye: İ.DH. 1377/20 1318 Ca. 7/1 Eylül 1900; İ.DH. 1410/20 1321 Ra. 05/01 Haziran 1903; İ..DH. 1412/28 1321 Ca. 17/11 Ağustos 1903.

Maârif Nezâreti: MF. MKT 730/22 1321 C. 1/25 Ağustos 1903.

Y1ldı, Perakende Evrakı Askerî Maruzat: Y..PRK.ASK. 202/104 1321 C. 8/1 Eylül 1903.

Y1ldız, Sadâret Husûsî Maruzât Evrâk1: Y..A...HUS 454/126 1321 Ca. 28/22 Ağustos 1903; Y..A...HUS. 456/4 1321 C. 10/3 Eylül 1903; Y..A...HUS 446/66 1321 M. 20/18 Nisan 1903.

\section{B. Gazeteler}

İkdam Gazetesi: No: 2464, 1319 M. 15/5 Mayıs 1901; No: 2475, 1319 M. 26/16 Mayıs 1901; No: 2476, 1319 M. 27/17 May1s 1901; No: 2478, 1319 M. 29/19 May1s 1901; No: 3177, 1321 M. 20/18 Nisan 1903; No: 3191, 1321 S. 4/2 May1s 1903; No: 3198, 1321 S. 10/8 May1s 1903; No: 3200, 1321 S. 13/11 May1s 1903; No: 3210, 1321 S. 23/21 Mayıs 1903; İkdam Gazetesi, No: 3218, 1321 Ra. 2/29 May1s 1903; No: 3221, 1321 Ra. 5/1 Haziran 1903; No: 3228, 1321 Ra. 12/8 Haziran 1903; No: 3245, 1321 Ra. 29/25 Haziran 1903; No: 3284, 1321 Ca. 9/3 Ağustos 1903; No: 3301, 1321 Ca. 26/20 Ağustos 1903; No: 3307, 1321 C. $2 / 26$ Ağustos 1903; No: 3309, 1321 C. 4/28 Ağustos 1903; No: 3316, 1321 C. 22/14 Eylül 1903; No: 3318, 1321 C. 24/16 Eylül 1903; No: 3332, 1321 R. 8/30 Eylül 1903; No: 3340, 1321 R. 16/8 Ekim 1903.

Sabah Gazetesi: No: 4839, 1321 M. 20/18 Nisan 1903; No: 4859, 1321 S. 10/8 Mayıs 1903; No: 4890, 1321 Ra. 12/8 Haziran 1903; No: 4907, 1321 Ra. 29/25 Haziran 1903; No: 4975, 1321 C. 9/1 Eylül 1903; No: 4883, 1321 Ra. 5/1 Haziran 1903; No: 4915, 1321 R. 7/3 Temmuz 1903; No: 4930, 1321 R. 22/18 Temmuz 1903; No: 4932, 1321 R. 24/20 Haziran 1903; No: 4967, 1321 C. 1/24 Ağustos 1903; No: 4969, 1321 C. $3 / 26$ Ağustos 1903; No: 4977, 1321 C. 11/3 Eylül 1903; No: 4974, 1321 C. 8/31 Ağustos 1903; No: 4979, 1321 C. 13/5 Eylül 
1903; No: 4990, 1321 C. 24/16 Eylül 1903; Sabah Gazetesi, No: 6074, 1324 B. 16/4 Eylül 1906.

Tercümanı Hakikat Gazetesi: No: 2668-7868, 1321 M. 22/20 Nisan 1903; No: 2710-7910, 1321 S. 4/2 May1s 1903; No: 2717-7917, 1321 S. 11/9 May1s 1903; No: 2719-7919, 1321 S. 13/11 May1s 1903; No: 2748-7948, 1321 S. 4/8 Haziran 1903; No: 2780-7980, 1321 R. 7/3 Temmuz 1903; No: 2793-7993, 1321 R. 29/25 Temmuz 1903; No: 2818-8018, 1321 Ca. 25/19 Ağustos 1903; No: 2846-8046, 1321 C. 24/16 Eylül 1903; No: 2857-8057, 1321 B. 5/27 Eylül 1903; No: 28618061, 1321 B. 9/1 Ekim 1903; No: 2897-8087, 1321 Ş. 6/27 Ekim 1903.

\section{Yayınlanmış Vesikalar}

Kadri, "Sergi-i Umumi-i Osmanî", Mecmua-i Fünun, No: 10, İstanbul, Cemiyet-i İlmiye-i Osmaniye, 1279.

Kadri, "Tarih-i Sergi-yi Ber-Vech-i Umumi”, Mecmua-i Fünun, No: 9, İstanbul, Cemiyet-i İlmiye-i Osmaniye, 1279.

Münif, "Sergi-i Umumi Osmaniyeden Vuku-1 Küşadı", Мecmua-i Fünun, No: 9, İstanbul, Cemiyet-i İlmiye-i Osmaniye, 1279.

Sivas Vilayet Salnamesi, Sivas, Sivas Vilayet Matbaas1, Def'a 16, 1321.

Sivas Vilayet Salnamesi, Sivas, Sivas Vilayet Matbaası, Def'a 17, 1325.

\section{Araştırma ve İnceleme Eserler}

Akçura, Gökhan, Türkiye Sergicilik ve Fuarcılık Tarihi, İstanbul, Tarih Vakfı Yayınevi, 2009.

Ayverdi, İlhan, Misalli Büyük Türkçe Sözlük, İstanbul, Kubbealtı Yayınları, 2011.

Balcı, Ercüment, “Birinci Dünya Savaşı Yıllarında Batı Anadolu’da Mahalli Bir Fuar: Biga Sanayi ve Zirai Ürünler Sergisi (7 Eylül-7 Kasım 1916)”, Türk Dünyası Araştırmaları, S. 146, 2003.

Balc1, Ercüment, "İstanbul'un İlk Büyük Uluslararası Fuarı: Sergi-i Umumî-i Osmanî (1863)", Antikçă̆'dan XXI. Yüzyıla Büyük İstanbul Tarihi, C. IV, İstanbul, İstanbul BB. Kültür Yayınları, 2015.

Demir, Kenan, “Sergi-i Umumi-i Osmani’nin (1863) Açılışı ve Sergi’nin Duyurulmasında Gazetelerin Rolü”, Firat Üniversitesi Sosyal Bilimler Dergisi, C. 28, S. 1, 2018.

Ergüney, Yeşim Duygu - Kara Pilehvarian, Nuran, “On Dokuzuncu Yüzyılda Dünya Fuarlarında Osmanlı Temsiliyeti”, Megaron, C. 10, S. 2, 2015. 
Germaner, Semra, "Osmanlı İmparatorluğu'nun Uluslararası Sergilere Katıl1m1 ve Kültürel Sonuçları”, Tarih ve Toplum Dergisi, S. 95, 1991.

Kanca, Haluk, "XIX. Yüzyılın İkinci Yarısında Uluslararası Osmanlı Fuarı: 1863 Sergi-i Umumi-i Osmani”, Muhasebe ve Finans Tarihi Araştırmaları Dergisi, S. 5, 2013.

Muşmal, Hüseyin, "1901 Yılında Konya'da Açılan Hal1-Kilim Sergisi ve 1899 Tarihli Sergi Talimatnamesi”, I. Uluslararası Türk El Dokumaları Kongresi Bildirileri, Konya, S.Ü Selçuklu Araştırmaları Merkezi Başkanlığı Yayınları, ed. Ahmet Aytaç, 2007.

Öney, Ayhan, İktisadi ve Ticari Terimler Sözlüğ̈̈, Ankara, Turhan Kitabevi, 1978.

Önsoy, Rıfat, "Osmanlı İmparatorluğunun Katıldığı İlk Uluslararası Sergiler ve Sergi-i Umumi Osmani (1863 İstanbul Sergisi)”, Belleten, C. 47, S. 185, 1983.

Tekdemir, Aziz, "1867 Paris Sergisi ve Sultan Abdülaziz'in Sergiyi Ziyareti”, Trakya Üniversitesi Edebiyat Fakültesi Dergisi, C. 3, S. 6, 2013. 
Ek.1 Sivas Hamidiye Sınaat ve Ziraat Sergisi’nin Açılış Töreni

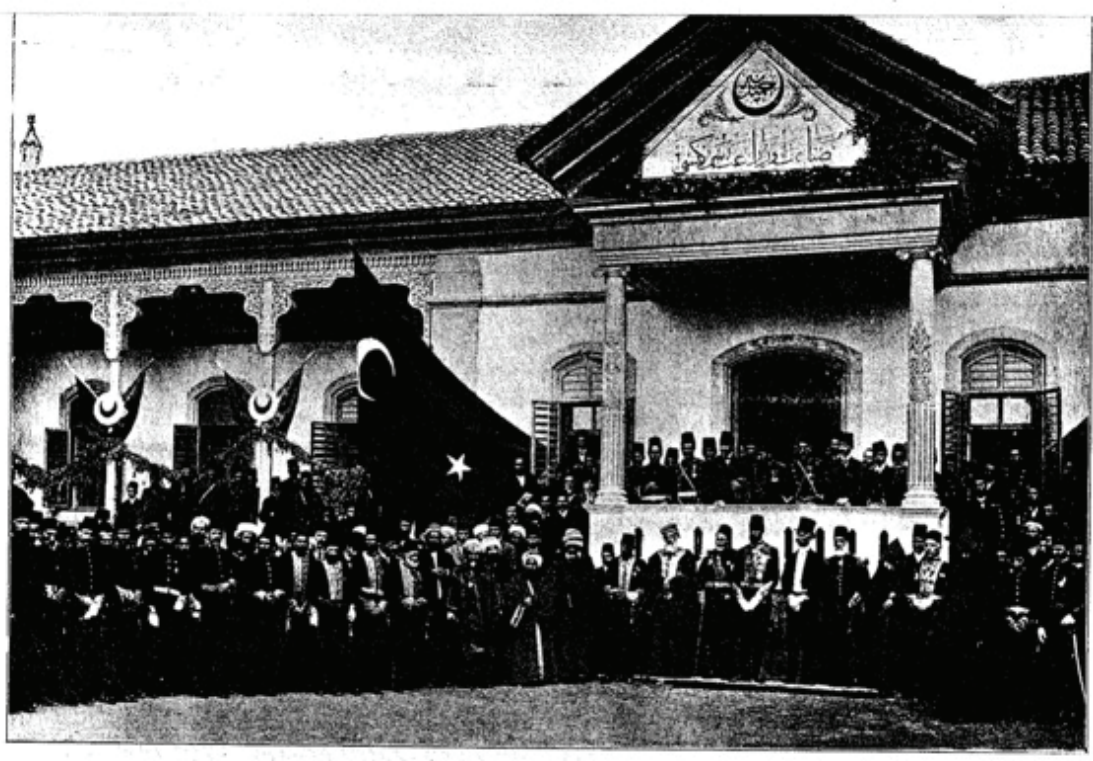

Ek.2 Sivas Hamidiye Sinaat ve Ziraat Sergisi'nin Hatırası İpek Mendil

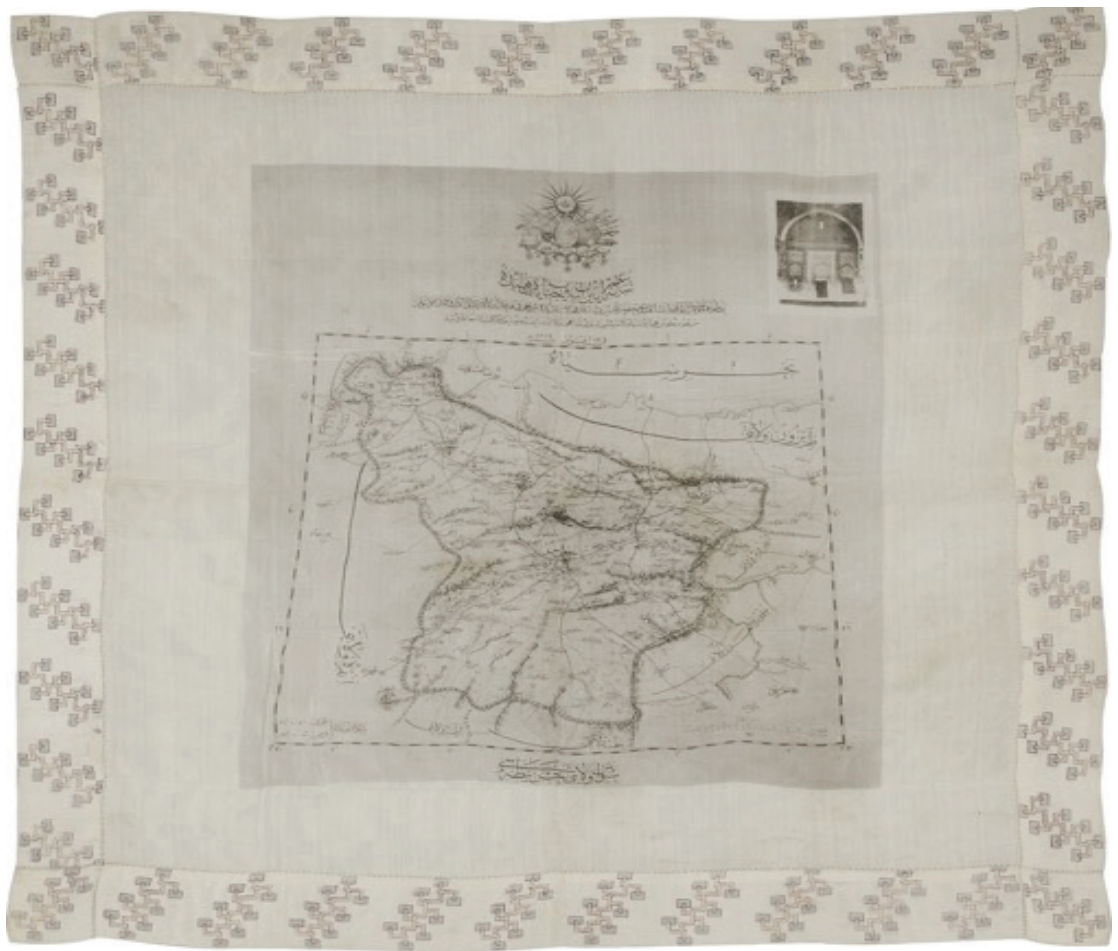


